\title{
Udział przedstawicieli nauki w pracach nad kodyfikacją materialnego prawa wykroczeń w Polsce Ludowej ${ }^{1}$
}

I. Niniejszy artykuł porusza zagadnienie udziału przedstawicieli nauki w pracach nad kodyfikacją materialnego prawa wykroczeń Polski Ludowej, które miały miejsce w latach 1960-1971. Z uwagi na podyktowaną względami redakcyjnymi ograniczoną objętość opracowania, Autor skoncentrował się na najważniejszych jego zdaniem problemach poruszanych przez doktrynę w związku z prowadzonymi pracami kodyfikacyjnymi. Sposób rozstrzygnięcia omówionych $\mathrm{w}$ niniejszym artykule zagadnień determinował nie tylko kształt podstawowych instytucji materialnego prawa wykroczeń, lecz także jego pozycję w systemie prawa Polski Ludowej.

Potrzeba skodyfikowania materialnego prawa wykroczeń była silnie odczuwana w praktyce funkcjonowania orzecznictwa karno-administracyjnego okresu gomułkowskiego, gdyż organy rozpatrujące sprawy o wykroczenia posługiwały się pochodzącym z 1932 r. rozporządzeniem Prezydenta RP Prawo o wykroczeniach ${ }^{2}$ (p.ow.). W myśl zawartej w p.ow. definicji formalnej wykroczeniem był czyn zagrożony karami zasadniczymi - aresztu do 3 miesięcy i grzywny do 3000 złotych albo jedną z tych kar. Względy natury praktycznej legły u podstaw uregulowania problematyki wykroczeń w odrębnej kodyfikacji jako czynów podlegających jurysdykcji organów administracji ogólnej, które sprawowały orzecznictwo w zastępstwie sądów. Wyrazem subsydiarnego charakteru orzecznictwa karno-administracyjnego było przysługu-

${ }^{1}$ Projekt badawczy został sfinansowany ze środków Narodowego Centrum Nauki jako projekt badawczy własny nr NN110189540.

${ }^{2}$ Rozporządzenie Prezydenta Rzeczypospolitej Polskiej z dnia 11 lipca 1932 r. Prawo o wykroczeniach (Dz. U. nr 60, poz. 573). 
jące osobie ukaranej prawo żądania rozpatrzenia sprawy o wykroczenie przez sąd powszechny ${ }^{3}$.

Traktowane jako odrębna od przestępstw kategoria czynów karalnych wykroczenia różniły się od zamieszczonych w kodeksie karnym występków jedynie wysokością grożącej kary. Górna granica grożących sprawcy wykroczenia kar aresztu i grzywny wyznaczała zarazem minimalny próg kar przewidzianych za występek. Wydany równocześnie z p.ow. kodeks karny ${ }^{4}$ określał występek jako czyn zagrożony karą powyżej 3 miesięcy aresztu i 3000 złotych. W II Rzeczypospolitej prawo wykroczeń traktowano jako część składową prawa karnego sensu largo. Wobec ścisłego merytorycznego powiązania z kodeksem karnym p.ow. zawierało odesłania do 21 przepisów części ogólnej tego kodeksu. Przepisy te poruszały kwestie winy, indywidualizacji odpowiedzialności, okoliczności wyłączających oraz ograniczających poczytalność, a także ogólnych zasad wymiaru kary. W samodzielny sposób p.ow. regulowało zasady odpowiedzialności za wykroczenie oraz szczególne zasady wymiaru kary 5 .

Sięgająca korzeniami okresu międzywojennego pierwsza polska kodyfikacja materialnego prawa wykroczeń stała na dobrym poziomie legislacyjnym, lecz w realiach Polski Ludowej uległa daleko posuniętej dezaktualizacji. Z uwagi na bliski związek prawa wykroczeń z problemami życia codziennego podkreślano potrzebę periodycznej korektury jego przepisów w sposób odpowiadający ,aktualnym stosunkom społecznym i potrzebom państwowym”. Zachodzące z Polsce po II wojnie światowej przemiany społeczno-ustrojowe stawiały pod znakiem zapytania zasadność dalszego obowiązywania p.ow. jako aktu prawnego uchwalonego ,w przedwojennych kapitalistycznych stosunkach”. Twierdzono, iż zawarte w p.ow. rozwiązania ,nie zawsze nadają się do tego, by w pełni zaspokoić nowe odmienne potrzeby związane z budownictwem ustroju socjalistycznego"7. Wprawdzie p.ow. po wojnie zostało poddane trzykrotnej nowelizacji, lecz w sposób bardzo fragmentaryczny ${ }^{8}$.

Wobec powierzchownego charakteru nowelizacje nie były w stanie zapobiec procesowi stopniowej dezaktualizacji poszczególnych przepisów p.ow., zapoczątkowanej uchwaleniem w dniu 15 grudnia $1951 \mathrm{r}$. ustawy o orzecznictwie karno-administracyjnym ${ }^{9}$ (u.k.a.). W miejsce jednoosobowego orzecz-

${ }^{3}$ M. Siewierski, J. Nisenson, Kodeks karny i prawo o wykroczeniach, Warszawa 1935, s. 219.

${ }^{4}$ Rozporządzenie Prezydenta Rzeczypospolitej Polskiej z dnia 11 lipca 1932 r. kodeks karny (Dz. U. nr 60, poz. 571).

5 J. Jakubowska-Hara, Grzywna w prawie wykroczeń. Model ustawowy i praktyka, Warszawa 2004, s. 20-21.

${ }^{6}$ T. Tyrawski, Projekt nowego prawa o wykroczeniach, „Wojskowy Przegląd Prawniczy” 1962, nr 1, s. 45.

${ }^{7}$ Projekt Prawa o wykroczeniach, Warszawa 1961, s. 45.

${ }^{8}$ T. Tyrawski, op. cit., s. 45.

9 Dz. U. nr 66, poz. 454. 
nictwa sprawowanego przez czynnik urzędniczy ${ }^{10}$ wprowadzono kolegialne rozpatrywanie spraw o wykroczenia z udziałem czynnika społecznego. W tym celu utworzono kolegia orzekające, które w okresie gomułkowskim określano mianem kolegiów karno-administracyjnych (dalej kolegia). Kolegia były usytuowane przy terenowych organach administracji państwowej, czyli prezydiach rad narodowych wszystkich szczebli podziału terytorialnego kraju ${ }^{11}$. Obsługą organizacyjno-prawną kolegiów zajmowały się wydziały i urzędy spraw wewnętrznych prezydiów powiatowych (wydziały) i wojewódzkich (urzędy) rad narodowych ${ }^{12}$. Silne powiązania instytucjonalne kolegiów z administracją stwarzał system nadzoru nad ich orzecznictwem. Nadzór ten sprawowany był przez prezydia rad narodowych i wyrażał się w prawie uchylania prawomocnych orzeczeń kolegiów. Z kolei minister spraw wewnętrznych sprawował tzw. zwierzchni nadzór, w ramach którego wydawał wiążące kolegia wytyczne dotyczące polityki karnej w sprawach o wykroczenia. Minister wykonywał przysługujące mu kompetencje przy pomocy Wydziału Karno-Administracyjnego. Wydział ten stanowił jednostkę organizacyjną utworzonego w 1958 r. Departamentu Społeczno-Administracyjnego (DSA) MSW ${ }^{13}$.

Zawierająca regulacje $\mathrm{z}$ dziedziny materialnego prawa wykroczeń u.k.a. istotnie ograniczyła stosowanie przez kolegia części ogólnej p.ow. Natomiast przewidziane w jego części szczególnej stany faktyczne wykroczeń stopniowo traciły rację bytu wskutek wydawania szeregu ustaw specjalnych regulujących ważniejsze problemy życia społecznego. Na początku lat sześćdziesiątych około $90 \%$ spraw rozpatrywanych przez kolegia dotyczyło wykroczeń zawartych $\mathrm{w}$ około dwustu aktach prawnych o charakterze szczególnym wobec pochodzącej z 1932 r. kodyfikacji. Ustawy szczególne zawierały „blisko 1700 , często bardzo złożonych, stanów faktycznych wykroczeń" ${ }^{14}$. Na pierwszym miejscu listy wykroczeń rozpatrywanych przez kolegia w okresie gomułkowskim znajdowały się sprawy o zakłócenie porządku publicznego lub wywołanie zgorszenia przez osoby znajdujące się w stanie nietrzeźwości.

10 Przed wejściem w życie u.k.a. sprawy o wykroczenia rozpatrywane były przez referentów karno-administracyjnych na podstawie rozporządzenia Prezydenta RP z 22 marca 1928 r. O postępowaniu karno-administracyjnym (Dz. U. nr 75, poz. 444).

${ }^{11}$ K. Siarkiewicz, Ksztaltowanie się ustroju kolegiów, „Zagadnienia Wykroczeń” 1977, nr 4-5, s. 36.

12 Z. Leoński, Kolegia w systemie organów rady narodowej, „Zagadnienia Karno-Administracyjne” („ZKA”) 1968, nr 6, s. 20-21.

13 Zarządzenie Ministra Spraw Wewnętrznych z dnia 28 czerwca 1958 r. w sprawie zakresu działania Departamentu Społeczno-Administracyjnego Ministerstwa Spraw Wewnętrznych (Dz. U. MSW nr 23, poz. 72 z dn. 10 lipca 1958 r.). Instytut Pamięci Narodowej w Warszawie, Biuro Udostępniania i Archiwizacji Dokumentów, zespół akt Ministerstwo Spraw Wewnętrznych II, sygn. teczki 1919, s. 4 (IPN BU MSW II 1919, s. 4).

14 Porównanie ilości wniosków o ukaranie w kolegiach k-a za wykroczenia objęte prawem o wykroczeniach z 1932 r. i projektem prawa o wykroczeniach z 1968 r. z ogólnym wpływem wniosków do kolegiów, IPN BU MSW II 514, część II , s. 429. 
Podstawa karalności tzw. wykroczeń alkoholowo-chuligańskich była ustawa z 10 grudnia 1959 r. o zwalczaniu alkoholizmu ${ }^{15}$. Stosowny artykuł tej ustawy obejmował liczne stany faktyczne związane z naruszeniem porządku i spokoju publicznego, przez co pochłaniał dyspozycje trzech najczęściej stosowanych w praktyce przepisów p.ow. Drugą pozycję zajmowały rozproszone pomiędzy różne akty prawne wykroczenia przeciwko bezpieczeństwu ruchu drogowego. W jedną całość zebrała je ustawa z 27 listopada $1961 \mathrm{r}$. o bezpieczeństwie i porzadku ruchu na drogach publicznych ${ }^{16}$. Tego rodzaju czyny w ogóle nie posiadały swojego odpowiednika w obowiązującym p.ow. W drugiej połowie lat sześćdziesiątych wykroczenia alkoholowo-chuligańskie oraz drogowe stanowiły łącznie $75 \%$ spraw rozpatrywanych przez kolegia ${ }^{17}$.

Fakt obowiązywania dużej liczby przepisów materialnego prawa wykroczeń „rozrzuconych w źródłach prawnych różnego szczebla i pochodzących z różnych okresów historycznych" wpływał negatywnie na poziom funkcjonowania orzecznictwa karno-administracyjnego. Trudności z poruszaniem się w gąszczu przepisów miały zarówno funkcjonujące w oparciu o czynnik społeczny kolegia, jak też pełniące rolę oskarżyciela publicznego w postępowaniu karno-administracyjnym organy Milicji Obywatelskiej. Trudności natury praktycznej potęgował fakt niemal zupełnego braku zainteresowania nauki problematyką prawa wykroczeń, które w okresie obowiązywania u.k.a określano mianem prawo karno-administracyjne. Nawiązując do dorobku nauki radzieckiej definiowano wykroczenia oraz kary przewidziane wobec ich sprawców jako ,administracyjne" 18 .

Jeszcze na początku lat sześćdziesiątych prawo karno-administracyjne stanowiło „dziedzinę prawie całkowicie zapomnianą” przez przedstawicieli nauki ${ }^{19}$. W powojennej bibliografii prawniczej przez długi czas brakowało ,jakiegokolwiek opracowania monograficznego z tego zakresu” oraz ,jakiejkolwiek analizy orzecznictwa karno-administracyjnego". Pochodząca z 1961 r. opinia karnisty z UW L. Kubickiego pozostała aktualna aż drugiej połowy lat sześćdziesiątych, kiedy to na fali prac kodyfikacyjnych prawa wykroczeń zaczęły ukazywać się pierwsze monografie o charakterze teoretycznym poświęcone tej dziedzinie prawa ${ }^{20}$. Niemal zupełny brak zainteresowania doktryny

15 Dz. U. nr 69, poz. 434.

16 Dz. U. nr 53, poz. 295.

17 D. Egierska-Pakuła, Projekt prawa o wykroczeniach, „ZKA” 1967, nr 5, s. 33.

18 A. Marek, Proponowany model prawa wykroczeń i orzecznictwa w sprawach o wykroczenia na tle standardów europejskich, w: T. Bojarski, M. Mozgawa, J. Szumski (red.), Rozwój polskiego prawa wykroczeń, Lublin 1996, s. 27.

19 L. Kubicki, Projekt prawa o wykroczeniach, „Państwo i Prawo” („PiP”) 1961, nr 10, s. $493-$ -494 .

${ }^{20}$ Przed 1967 r. ukazało się zaledwie jedno opracowanie poświęcone części ogólnej prawa wykroczeń, lecz pochodząca z 1955 r. książka R. Rajkowskego, Prawo karno-administra- 
przekładał się na sferę edukacji prawniczej, wskutek czego prawo wykroczeń zajmowało marginesową pozycję w programach studiów uniwersyteckich. Jako prawo karno-administracyjne było omawiane przy okazji wykładów $\mathrm{z}$ prawa administracyjnego. $\mathrm{Z}$ kolei postępowania $\mathrm{w}$ sprawach o wykroczenia nauczono jako szczególnego trybu procedury administracyjnej. Po przełomie 1956 r. jedynie MSW podejmowało odosobnione wysiłki zmierzające do popularyzacji prawa wykroczeń. Wydawane pod auspicjami tego resortu specjalistyczne czasopismo „Zagadnienia Karno-Administracyjne” koncentrowało się głównie na kwestiach praktycznych, związanych z bieżącą działalnością kolegiów ${ }^{21}$.

II. Podstawową przyczyną marginalnego traktowania prawa wykroczeń przez doktrynę był niski poziom legislacji w tej dziedzinie, który zdaniem środowiska prawniczego stanowił pochodną złego stanu ogólnego ustawodawstwa administracyjnego Polski Ludowej. Dlatego z dużą nadzieją powitano, podjętą przez Radę Ministrów w dniu 15 października 1959 r., uchwałę w sprawie uporządkowania ustawodawstwa administracyjnego. Uchwała zakładała podjęcie przez poszczególne resorty szeroko zakrojonych prac kodyfikacyjnych i przedstawienie stosownych projektów 82 aktów prawnych w terminie do końca $1960 \mathrm{r}^{22}$ Zakres tych prac miał obejmować również dziedzinę prawa karno-administracyjnego, które czynniki oficjalne traktowały jako część składową prawa administracyjnego z uwagi na bliski związek szeregu wykroczeń z działalnością administracji państwowej ${ }^{23}$.

W wykonaniu uchwały RM, wspólnym zarządzeniem ministrów spraw wewnętrznych i sprawiedliwości z dnia 30 marca 1960 r., powołano Komisję do opracowania projektu Prawa o Wykroczeniach (dalej zwanej Komisją). W skład komisji weszli przedstawiciele świata nauki, sędzia Sądu Najwyższego $^{24}$, wiceprokuratorzy Generalnej Prokuratury PRL, pracownicy DSA MSW oraz urzędów spraw wewnętrznych prezydiów wojewódzkich rad narodowych. Na jej czele stanął karnista J. Bafia, który łączył pracę naukową na UW z pełnieniem funkcji dyrektora Departamentu Prawno-Organizacyjnego resortu sprawiedliwości. Na jego zastępcę powołano naczelnika Wydziału Karno-Administracyjnego DSA MSW Z. Orłowskiego. Środowisko naukowe

cyjne Polski Ludowej miała bardziej charakter praktycznego poradnika dla członków kolegiów orzekających niż rzetelnego opracowania o charakterze naukowym. Poza tym wydane na początku 1955 r. dzieło zawierało liczne rozważania natury ideologicznej oraz odniesienia do dorobku nauki radzieckiej, wskutek czego po przełomie październikowym zostało krytycznie oceniane jako wyraz dogmatyzmu ideologicznego w nauce socjalistycznej okresu stalinowskiego.

${ }^{21}$ L. Kubicki, op. cit., s. 493.

${ }^{22}$ Notatka DSA MSW w sprawie prac nad kodyfikacja prawa karno-administracyjnego materialnego, IPN BU MSW II 6443, s. 193.

${ }^{23}$ L. Kubicki, op. cit., 493-494.

${ }^{24}$ Był nim sędzia Sądu Najwyższego K. Czajkowski. 
reprezentowali: przedstawiciel nauki prawa karnego - L. Lernell z UW oraz dwaj administratywiści - W. Brzeziński (UJ) oraz zatrudniony na UW J. Służewski ${ }^{25}$.

Przewaga naukowców zajmujących się prawem administracyjnym stanowiła pochodną ustaleń odnośnie do składu personalnego komisji poczynionych przez kierownictwo resortów spraw wewnętrznych i sprawiedliwości. Podczas konsultacji międzyresortowych uprzywilejowaną pozycję zajmował minister spraw wewnętrznych z racji sprawowania zwierzchniego nadzoru nad orzecznictwem karno-administracyjnym. Wpływ resortu sprawiedliwości na kształtowanie polityki karnej w sprawach o wykroczenia był niewielki, gdyż po reformie u.k.a. z grudnia 1958 r. sądy powszechne rozpatrywały odwołania od orzeczeń kolegiów o ukaraniu aresztem zasadniczym ${ }^{26}$. W przypadku orzeczenia innych kar, zwłaszcza najczęściej stosownej w praktyce grzywny, obowiązywał zaczerpnięty z procedury administracyjnej model wnoszenia środka odwoławczego do kolegium drugiej instancji ${ }^{27}$.

Z obawy przez osłabieniem swojej pozycji resort spraw wewnętrznych stał na gruncie stworzonej $\mathrm{w}$ okresie stalinowskim administracyjnej koncepcji prawa wykroczeń. Jego reprezentant w składzie Komisji Z. Orłowski twierdził, iż ,prawo karno-administracyjne materialne jest funkcją ustawodawstwa administracyjnego, jest wynikową tego ustawodawstwa, jest jego produktem". Jego zdaniem materialne prawo karno-administracyjne pełniło funkcję służebną wobec ustawodawstwa administracyjnego, gdyż miało na celu zabezpieczenie realizacji zadań stojących przed administracją w drodze stosowania sankcji karnych. Fakt występowania ścisłej zależności pomiędzy prawem wykroczeń a ustawodawstwem administracyjnym Orłowski podniósł jako argument przeciwko podejmowaniu zakrojonych na szeroką skalę prac kodyfikacyjnych materialnego prawa karno-administracyjnego. Uważał, że miałyby one rację bytu dopiero po „ostatecznym ukształtowaniu i uporządkowaniu ustawodawstwa administracyjnego"28.

${ }^{25}$ Zarządzenie $n r$ 66/60 Ministrów Spraw Wewnętrznych i Sprawiedliwości z dnia 30 marca 1960 r. w sprawie powołania Komisji do opracowania projektu Prawa o Wykroczeniach, Archiwum Akt Nowych, zespół akt Ministerstwo Sprawiedliwości, sygn. teczki 1963, s. 9-10 ( AAN Min. Spr. 1963, s. 9-10).

${ }^{26}$ Gruntowna reforma wprowadzonego przez u.ok.a. socjalistycznego modelu orzecznictwa w sprawach wykroczenia, wyrażająca się m.in. w częściowym (za enumeratywnie określone wykroczenia) przywróceniu kary aresztu zasadniczego, została przeprowadzona na mocy ustawy z dnia 2 grudnia 1958 r. o zmianie ustawy z dnia 15 grudnia 1951 r. o orzecznictwie karno-administracyjnym (Dz. U. nr 77, poz. 396).

27 J. Szumski, Środki penalne w polskim prawie wykroczeń na tle doświadczeń praktyki, Lublin 1995, s. 41.

${ }^{28}$ Uchwała Rady Ministrów wyznaczyła końcowy termin prac nad uporządkowaniem ustawodawstwa administracyjnego na 31 grudnia 1960 r. Notatka DSA MSW w sprawie prac nad kodyfikacja prawa karno-administracyjnego materialnego, IPN BU MSW II 6443, s. 193. 
Jednak decydujący wpływ na podjęcie przez czynniki oficjalne decyzji o skodyfikowaniu materialnego prawa wykroczeń przy okazji prac nad uporządkowaniem ustawodawstwa administracyjnego wywarły przesłanki natury praktycznej oraz spodziewany wydźwięk propagandowy takiego przedsięwzięcia. Oficjalna inauguracja działalności Komisji miejsce w dniu 30 kwietnia 1960 r., kiedy to odbyło się pierwsze posiedzenie jej Sekretariatu ${ }^{29}$. Owocem tego posiedzenia była uchwała w sprawie ogólnej koncepcji prac kodyfikacyjnych, które miały być prowadzone w oparciu o założenie ,odcięcia się od Kodeksu karnego i sądów”. Część ogólna przyszłego projektu miała nawiązywać do obowiązującej u.k.a., gdyż jej przepisy materialne zawierały „własne sformułowania, charakteryzujące odrębność orzecznictwa karno-administracyjnego". Z kolei część szczególna miał być ,uaktualniona i poszerzona o niektóre przepisy obowiązujących obecnie obok p.ow. ustaw szczególnych"30. W oparciu o powyższe założenia Sekretariat Komisji przygotował tezy do części ogólnej oraz propozycje dotyczące zakresu i metody prac nad częścią szczególną nowego prawa o wykroczeniach. W czerwcu 1960 r. zostały one zaakceptowane przez obradującą po raz pierwszy w pełnym składzie Komisję.

III. Rezultatem 15-miesięcznych prac Komisji był ogłoszony w czerwcu $1961 \mathrm{r}$. w postaci specjalnej broszury projekt prawa o wykroczeniach ${ }^{31}$ (projekt z 1961 r.). Kluczowa dla konstrukcji części ogólnej przyszłej kodyfikacji kwestia miejsca prawa wykroczeń w systemie prawa Polski Ludowej została rozstrzygnięta wbrew stanowisku resortu spraw wewnętrznych. Uczestniczący w pracach Komisji przedstawiciele nauki, w tym zapraszani na jej posiedzenia w charakterze rzeczoznawców wybitni karniści J. Sawicki oraz M. Siewierski, poddali ostrej krytyce założenie przynależności prawa wykroczeń do prawa administracyjnego. Ich zdaniem zaczerpnięta z literatury radzieckiej koncepcja traktowania wykroczenia jako deliktu administracyjnego straciła całkowicie rację bytu wraz z upadkiem dogmatyzmu ideologicznego w nauce socjalistycznej. Próby jej reaktywowania na początku lat 60 . oceniono jako działania służące uzasadnieniu dalszego funkcjonowania orzecznictwa w sprawach o wykroczenia w strukturach resortu spraw wewnętrznych.

${ }^{29}$ Sekretariat Komisji tworzyło dwóch przedstawicieli MSW zajmujących stanowiska starszego radcy w DSA oraz reprezentujący Departament Ustawodawczy resortu sprawiedliwości starszy radca i sędzia. Wydany wraz z zarządzeniem powołującym do życia Komisje regulamin stanowił, iż Sekretariat jest, ,jej permanentnie pracującym organem roboczym, opracowującym projekty w przedmiocie stanowiącym zakres prac Komisji”. Zarządzenie nr 66/60 Ministrów Spraw Wewnętrznych i Sprawiedliwości z dnia 30 marca 1960 r. w sprawie powołania Komisji do opracowania projektu Prawa o Wykroczeniach, AAN Min. Spr. 1963, s. 11.

${ }^{30}$ Pismo naczelnika Wydziału Karno-Administracyjnego DSA MSW Z. Orlowskiego w sprawie ogólnych wyników posiedzenia komisji do spraw opracowania projektu prawa o wykroczeniach $z$ dnia 12 lipca 1960 r. IPN BU MSW II 6627, s. 123-124.

${ }^{31}$ Prawo o wykroczeniach. Projekt, Warszawa 1961. 
Krytyczna ocena poglądów głoszonych przez przedstawicieli tego resortu nie oznaczała bynajmniej powrotu do przedwojennych teorii zaliczających wprost wykroczenia do kategorii przestępstw. Rozwianiu obaw MSW przed ,usądowieniem" prawa wykroczeń służyło zamieszczone w uzasadnieniu projektu z 1961 r. następującego stwierdzenia: ,prawo o wykroczeniach jest odrębnym działem prawa karnego traktującym o czynach społecznie niebezpiecznych, które nie są przestępstwami, lecz których popełnienie jest karalne" ${ }^{32}$. Stwierdzenie to należy ocenić jako próbę odejścia od administracyjnej koncepcji prawa wykroczeń na rzecz podkreślenia jego przynależności do obszaru szeroko pojmowanego prawa karnego.

Jednocześnie z uwagi na bliski związek szeregu stanów faktycznych wykroczeń z działalnością administracji wskazywano na potrzebę całkowitego oderwania przyszłej kodyfikacji od części ogólnej kodeksu karnego. Podkreśleniu różnicy pomiędzy przestępstwem a wykroczeniem służyło wprowadzenie kryterium stopnia społecznego niebezpieczeństwa czynu, którego nie znało operujące formalną definicją wykroczenia przedwojenne p.ow. Na tle szczególnie niebezpiecznych przestępstw wykroczenia miały stanowić czyny mniejszej wagi. Cechować je miał nieznaczny, a nawet znikomy stopień społecznego niebezpieczeństwa ${ }^{33}$. Projekt z 1961 r. podkreślał także odrębność kar orzekanych za wykroczenia od kar wymierzanych za zbrodnie i występki, określając te pierwsze mianem kar administracyjnych. Stworzona w oparciu o powyższe założenia definicja określała wykroczenie ,jako czyn zabroniony przez ustawę obowiązującą w czasie jego popełnienia, społecznie niebezpieczny, nie będący przestępstwem i zagrożony karami administracyjnymi"34. Część ogólna projektu liczyła 35 artykułów (projekt z 1961 r. składał się łącznie z 122 artykułów), które w ocenie L. Kubickiego stanowiły ,ambitną i bardzo ciekawą próbę nowego ujęcia szeregu podstawowych instytucji prawa karnego”. Autor tej opinii wskazywał w szczególności na „zupełnie nowe konstrukcje winy, błędu, stanu wyższej konieczności” czy też „nieznany dotąd naszemu ustawodawstwu katalog okoliczności obciążających i łagodzących"35.

IV. Projekt z 1961 r. został poddany dyskusji środowiskowej, podczas której najwięcej kontrowersji wśród przedstawicieli nauki prawa budziła zawarta w nim definicja wykroczenia. Doktrynalnego uzasadnienia stanowiska Komisji podjął się jeden z jej członków - L. Lernell, którego zdaniem nale-

32 Ibidem, s. 44. s. 1074.

33 L. Hochberg, Kodyfikacja przepisów o wykroczeniach, „Nowe Prawo” („NP”) 1969, nr 9,

34 Pismo naczelnika Wydziału Karno-Administracyjnego DSA MSW Z. Orłowskiego w sprawie ogólnych wyników posiedzenia komisji do spraw opracowania projektu prawa o wykroczeniach z dnia 12 lipca 1960 r. IPN BU MSW II 6627, s. 124.

35 L. Kubicki, op. cit., s. 495. 
żało radykalnie odgraniczyć sferę wykroczeń od sfery przestępstw. W związku z tym wskazywał na słuszność wprowadzenia pojęcia stopnia społecznego niebezpieczeństwa czynu jako kryterium najlepiej oddającego różnicę pomiędzy wykroczeniem a przestępstwem. W przypadku wykroczeń społeczne niebezpieczeństwo naruszenia określonych dóbr było znacznie dalsze niż przy przestępstwach ${ }^{36}$. Warunkowane stopniem społecznego niebezpieczeństwa czynu granice pomiędzy przestępstwem i wykroczeniem ustawodawca wytyczał poprzez określenie maksymalnego zagrożenia karnego. Jednakże odmienności kar przewidzianych za wykroczenie wobec kar grożących za przestępstwo Lernell upatrywał nie tylko w zróżnicowaniu sankcji karnej. Wobec występowania różnicy jakościowej odmienny charakter miały posiadać kary wymierzane za każdy z tych dwóch rodzajów bezprawia. Ponieważ kara była „wyrazem oceny czynu i sprawcy, oceny jego stopnia społecznego niebezpieczeństwa", stąd zawierające mniejszy ładunek społecznego niebezpieczeństwa wykroczenia zagrożone były karami administracyjnymi, zaś wobec sprawców przestępstw stosowano kary kryminalne. Odmienny charakter kar miał być szczególnie widoczny w przypadku aresztu. Kara ta miała zastosowanie zarówno do wykroczeń jak i przestępstw, jako odpowiednio areszt administracyjny i areszt kryminalny. Według Lernella różnica nomenklatury pomiędzy aresztem orzekanym za wykroczenia i przestępstwa stanowiła argument przemawiający za odmiennym uregulowaniem prawnym sposobu wykonywania obu tych rodzajów kar o charakterze izolacyjnym ${ }^{37}$.

Pozostali uczestniczący w debacie środowiskowej przedstawiciele doktryny pozytywnie ocenili jedynie fakt wprowadzenia do projektu kryterium stopnia społecznego niebezpieczeństwa czynu, celem odróżnienia przestępstw od wykroczeń. Krytycznie odnieśli się do pomysłu wykorzystania tego kryterium w celu radykalnego odgraniczenia tych dwóch kategorii czynów karalnych, czego wyrazem miało być zawarte $\mathrm{w}$ art. 1 projektu stwierdzenie, iż wykroczenie nie jest przestępstwem. Przeciwnicy zaproponowanej przez Komisję definicji wykroczenia podkreślali fakt występowania pomiędzy przestępstwem a wykroczeniem różnicy o charakterze ilościowym, która przejawiała się w wysokości zagrożenia karnego ${ }^{38}$.

36 Jako przykład praktyczny Lernell wskazał wykroczenie polegające na niezaopatrzeniu zakładu pracy w urządzenia przeciwpożarowe, przy którym niebezpieczeństwo powstania pożaru było odległe. Znacznie bliższe niebezpieczeństwo pożaru miało miejsce w przypadku przestępstwa niszczenia urządzeń ochronnych w kopalni lub fabryce, czyli miejscach narażonych na niebezpieczeństwo powstania pożaru. Inny przykład to wykroczenie nielegalnego pobytu w strefie nadgranicznej, które stwarzało dogodne warunki dla przestępstwa polegającego na usiłowaniu nielegalnego przekroczenia granicy państwowej. Określenie wykroczenia w projekcie prawa o wykroczeniach, „ZKA” 1961, nr 2, s. 24.

${ }^{37}$ Ibidem, s. 25-26.

${ }^{38}$ Pismo naczelnika Wydzialu Karno-Administracyjnego DSA MSW Z. Orlowskiego w sprawie ogólnych wyników posiedzenia komisji do spraw opracowania projektu prawa o wykroczeniach 
Szczególnie krytycznie do zawartej w projekcie z 1961 r. definicji wykroczenia podszedł administratywista z UMCS E. Iserzon. Autor ten skupił się na wskazaniu błędów i niekonsekwencji tkwiących w poglądach Lernella. Według Iserzona cechujący przestępstwo większy ładunek społecznego niebezpieczeństwa nie mógł być traktowany jako kryterium „radykalnego odgraniczenia" sfery wykroczeń od sfery przestępstw. Różnica w stopniu społecznego niebezpieczeństwa tych dwóch kategorii czynów karalnych miała jedynie charakter ilościowy. Z praw logiki miała bowiem wynikać tożsamość rodzajowa zjawisk, z których jedno posiada te same cechy w stopniu mniejszym, natomiast drugie w stopniu większym. Odmienny stopień społecznego niebezpieczeństwa mogły posiadać nawet dwa zindywidualizowane przestępstwa godzące w takie same dobro chronione przez przepisy prawa karnego. W praktyce nie występowały bowiem czyny przestępne o identycznym ładunku społecznego niebezpieczeństwa. Iserzon krytycznie odniósł się także do poglądu o występowaniu kar administracyjnych jako specyficznych w swej treści środkach reakcji społecznej wobec sprawców wykroczeń. Podkreślał szereg podobieństw zachodzących pomiędzy karami orzekanymi przez kolegia i sądy. Obydwa rodzaje kar pełniły funkcje z zakresu prewencji generalnej i specjalnej, a u podstaw ich orzekania leżały względy wychowawcze ${ }^{39}$.

Podkreślając tożsamość rodzajową wykroczeń i przestępstw Iserzon zdecydowanie przeciwstawiał się przyjętemu przez Komisję założeniu samodzielnego charakteru części ogólnej projektu prawa o wykroczeniach względem przepisów kodeksu karnego. Szczególnie krytycznie ocenił zawarte w uzasadnieniu projektu stwierdzenie, iż przewidziane w nim rozwiązania miały być ,przejawem istniejącej obecnie tendencji do bardziej zdecydowanego odcięcia się orzecznictwa karno-administracyjnego od systemu prawa karnego". Zdaniem Iserzona nie można było mówić o jakiejkolwiek tendencji, skoro jedynym jej zwolennikiem był L. Lernell. Tendencja do niesprzeciwiania się dogmatycznemu założeniu, iż wykroczenie jest zjawiskiem gatunkowo odrębnym od przestępstwa, występowała w okresie stalinowskim i była podyktowana względami natury ideologiczno-politycznej ${ }^{40}$. Po 1956 r. nastąpił nieoficjalny powrót do głoszonych przez zachodnioeuropejską i polską naukę prawa okresu międzywojennego poglądów traktujących prawo wykroczeń jako integralną część prawa karnego. Świadczyć o tym miała przeprowadzona w grudniu 1958 r. gruntowna nowelizacja u.o.k.a., która przywracając częściowo sądową kontrolę orzecznictwa karno-administracyjnego opierała się na założeniu rodzajowej tożsamości wykroczeń i innych przestępstw ${ }^{41}$.

$z$ dnia 12 lipca $1960 r$. IPN BU MSW II 6627, s. 124.

39 E. Iserzon, Kierunki reformy orzecznictwa karno-administracyjnego, „PiP” 1961, nr 11, s. 778 .

40 E. Iserzon, Reforma orzecznictwa karno-administracyjnego, „PiP” 1959, nr 8-9, s. 255.

${ }^{41}$ Ibidem, s. 255. 
W opinii Iserzona ustawodawca nie widział zasadniczych różnic uzasadniających tworzenie części ogólnej prawa wykroczeń w oderwaniu od przepisów kodeksu karnego. Dlatego należało uznać za fakt bezsporny, iż „ogólna część prawa o wykroczeniach powinna być zharmonizowana z odnośnymi postanowieniami kodeksu karnego". Według tego autora system prawa danej społeczności powinien stanowić jedność ideologiczną i logiczną, która nie dopuszcza sprzecznych rozwiązań dla analogicznych sytuacji prawnych. Podsumowując swoje rozważania Iserzon podkreślał potrzebę przeprowadzenia reformy systemu prawa karno-administracyjnego w oparciu o dwa założenia wyjściowe. Według pierwszego z nich organy powołane do sprawowania wymiaru sprawiedliwości w zakresie wykroczeń powinny mieć charakter sądowy. Drugie zakładało przynależność wykroczeń do sfery przestępstw będących przedmiotem prawa karnego ${ }^{42}$.

Łagodniejszy w krytyce zaproponowanej przez Komisję definicji wykroczenia był L. Kubicki, który przyjęcie kryterium stopnia społecznego niebezpieczeństwa celem odgraniczenia wykroczeń od przestępstwami ocenił jako „pogląd trafny i nie budzący wątpliwości w socjalistycznej nauce prawa karnego". Natomiast podawał w wątpliwość założenie o jakościowym charakterze różnicy pomiędzy wykroczeniem a występkiem, skłaniając się ku poglądowi o braku zasadniczych odmienności pomiędzy tymi dwoma rodzajami czynów karalnych. Powołując się na poglądy Marksa podkreślał decydującą rolę ustawodawcy w procesie kwalifikowania określonego czynu zabronionego do sfery wykroczeń lub grupy występków. Kryteria składające się na ocenę ustawodawcy były różnorodne i stanowiły wypadkową wielu czynników, zwłaszcza względów natury organizacyjnej. Wyrazem ich znaczenia było nadanie rangi wykroczeń niektórym czynom stanowiącym dotychczas występki, co według uzasadniania projektu z 1961 r. miało „stworzyć sądom lepsze warunki do skoncentrowania większej uwagi na poważniejszych przestępstwach gospodarczych". Zmiana oceny stopnia społecznego niebezpieczeństwa czynów będących występkami nie została przeprowadzona w oparciu o analizę treści, lecz była determinowana przez czynniki natury organizacyjnej. Według Kubickiego występująca w ustawodawstwie wielu krajów płynna granica pomiędzy wykroczeniem a występkiem była dowodem na „nierozerwalne zespolenie zagadnienia katalogu wykroczeń z problemem katalogu występków i zbrodni”, które działają na zasadzie „naczyń połączonych”43.

Stojąc na gruncie teorii o tożsamości rodzajowej wykroczeń i przestępstw reprezentujący naukę prawa uczestnicy dyskusji środowiskowej domagali się rezygnacji $\mathrm{z}$ zamieszczenia $\mathrm{w}$ projekcie negatywnej definicji wykroczenia jako czynu nie będącego przestępstwem. Za skreśleniem zwrotu „,nie będą-

42 E. Iserzon, Kierunki reformy..., s. 778.

${ }^{43}$ L. Kubicki, op. cit., s. 498-499. 
cy przestępstwem" opowiedział się m.in. Sąd Najwyższy oraz Katedra Prawa Karnego UAM w Poznaniu. Opinie tych podmiotów zostały uznane przez Sekretariat Komisji za najbardziej reprezentatywne podczas podsumowania wyników dyskusji środowiskowej. Zdaniem Sądu Najwyższego pozbawienie wykroczenia charakteru przestępstwa budziło zastrzeżenia na tle ustawy karnej skarbowej z 1960 r., gdyż ustawa ta traktowała wykroczenia skarbowe jak przestępstwa. Z kolei Katedra Prawa Karnego UAM uzasadniała potrzebę skreślenia tego sformułowania względami techniki legislacyjnej, które nakazywały unikanie w definicjach określeń negatywnych oraz brakiem ustawowej definicji przestępstwa w projekcie nowego kodeksu karnego. Celem odróżnienia wykroczeń od przestępstw należało posługiwać się kryterium rodzaju i wysokości kary, co projekt czynił, przewidując zagrożenie karą administracyjną ${ }^{44}$.

V. Oprócz krytycznej oceny zawartej w projekcie definicji wykroczenia, uczestnicy dyskusji publicznej ,zakwestionowali celowość szybkiego opracowania projektu prawa o wykroczeniach i wyjścia z nim przed uchwaleniem nowego kodeksu karnego". Przeciwko poddaniu projektu z 1961 r. pod publiczną dyskusję przed opublikowaniem projektu kodeksu karnego opowiedziały się Prokuratura Generalna, Ministerstwo Obrony Narodowej oraz Zrzeszenie Prawników Polskich, a także niektórzy przedstawiciele doktryny na łamach czasopism prawniczych ${ }^{45}$. Za najlepiej oddające poglądy tej grupy uczestników debaty środowiskowej Sekretariat uznał wypowiedzi L. Kubickiego oraz reprezentanta Prokuratury Generalnej, a zarazem pracownika naukowego UŁ M. Siewierskiego. Punktem wyjścia krytycznych rozważań M. Siewierskiego było stwierdzenie, iż projekt z 1961 r. uwzględniał istniejący projekt nowego kodeksu karnego ,nie zawsze jednak podzielając jego sformułowania i często je korygując" 46 . Siewierski był przeciwny przenoszeniu do części ogólnej przyszłej kodyfikacji materialnego prawa wykroczeń rozwiązań przewidzianych w projekcie kodeksu karnego bez uprzedniej koordynacji takich działań przez zespoły pracujące nad projektami. Podkreślał, iż wcześniejsze skierowanie pod obrady Sejmu projektu prawa o wykroczeniach bez uzgodnienia z projektem kodeksu karnego prowadziłoby do ,poważnych trudności wszędzie tam, gdzie projekt prawa o wykroczeniach daje skorygowane sformułowania zaczerpnięte z projektu kodeksu karnego". Z uwagi na znaczenie przyszłego kodeksu karnego jako ,wyrazu dorobku myśli prawni-

${ }^{44}$ Notatka z 2 grudnia 1961 r. dotyczaca problemów wyniktych $w$ toku publicznej dyskusji nad projektem prawa o wykroczeniach, AAN Min. Spr. 1968, s. 5.

${ }^{45}$ Notatka przedstawiająca różnicę poglądów $w$ kwestiach prac na projektem prawa o wykroczeniach, AAN Min. Spr. 1967, s. 66.

46 Notatka z 2 grudnia 1961 r. dotyczaca problemów wyniklych $w$ toku publicznej dyskusji nad projektem prawa o wykroczeniach, AAN Min. Spr. 1968, s. 5. 
czej w Polsce Ludowej”, proces przenoszenia jego rozwiązań na grunt prawa wykroczeń powinien rozpocząć się dopiero w momencie zakończenia prac kodyfikacyjnych $\mathrm{w}$ dziedzinie prawa karnego ${ }^{47}$. Wzgląd na pełne skoordynowanie treści obydwu projektów miał przemawiać za odsunięciem w czasie prac kodyfikacyjnych materialnego prawa wykroczeń. W opinii Siewierskiego ewentualna zwłoka nie powinna przekroczyć kilku miesięcy, gdyż „kwestii rzeczywiście spornych pomiędzy projektami nie będzie zbyt wiele"48.

Z kolei L. Kubicki wskazywał na wzajemne powiązania pomiędzy prawem karnym i karno-administracyjnym, które ,narzucają naczelny postulat metodyczny, aby praca nad kodyfikacją prawa o wykroczeniach prowadzona była w ścisłym powiązaniu z pracami nad kodeksem karnym”. Ponieważ zakres przedmiotowy prawa karno-administracyjnego obejmował „resztówkę wydzieloną z obszaru prawa karnego", stąd próba ujęcia kodyfikacyjnego wykroczeń powinna być ostatnim etapem procesu kodyfikacji szeroko pojmowanego prawa karnego. Kubicki nawiązywał do doświadczeń Komisji Kodyfikacyjnej II Rzeczypospolitej, która prawem wykroczeń zajęła się dopiero po opracowaniu części szczególnej kodeksu karnego w pierwszym czytaniu ze względu na realną groźbę powstania luki ustawodawczej. Krytycznie ocenił brak w uzasadnieniu projektu z 1961 r. jakichkolwiek wzmianek o wykorzystaniu przez Komisję dotychczasowych materiałów kodyfikacyjnych w dziedzinie prawa karnego. Kluczową dla kształtu przyszłego prawa o wykroczeniach część ogólną opracowano bez jakiejkolwiek konsultacji z zespołem, który od lat przygotowywał kodeks karny. Dlatego „Komisja w dążeniu do oderwania projektu od norm innych kodyfikacji posunęła się stanowczo za daleko", nawet jeżeli część ogólna projektu prawa o wykroczeniach była w jakieś mierze wzorowana na jednej z redakcji projektu kodeksu karnego. Za działanie dalece nieprawidłowe Kubicki uznał inicjowanie szerokiej publicznej dyskusji nad „tak centralnymi problemami, jak np. nowe ujęcie winy, okoliczności wyłączających odpowiedzialność karną na tle prawa o wykroczeniach, a nie kodeksu karnego". Twierdził, że podstawowe problemy prawa karnego nie powinny być dyskutowane publicznie w związku z faktem wcześniejszego opracowania projektu prawa o wykroczeniach, gdyż „niewątpliwie zubożyłoby to zasięg dyskusji i bardzo ją zubożyło". Równie nietrafnym posunięciem było rozstrzyganie o głównych zasadach odpowiedzialności karno-administracyjnej w oderwaniu od części ogólnej kodeksu karnego ${ }^{49}$.

${ }^{47}$ M. Siewierski, W kwestiach węzłowych. Cztery uwagi krytyczne, „Prawo i Życie” („PiŻ”) 1961, nr 20, s. 2.

${ }^{48}$ Uwagi ogólne resortów do całości projektu Prawa o wykroczeniach z 1961 r., AAN Min. Spr. 1965, s. 11.

${ }^{49}$ Notatka z 2 grudnia 1961 r. dotyczaca problemów wynikłych $w$ toku publicznej dyskusji nad projektem prawa o wykroczeniach, AAN Min. Spr. 1968, s. 6-7. 
Podobne zastrzeżenia Kubicki wysunął pod adresem części szczególnej prawa o wykroczeniach, twierdząc, że „dyskusja nad każdym niemal stanem faktycznym wykroczenia wymaga konfrontacji jego ujęcia z odpowiednim, bliskim rodzajowo występkiem”. Podczas takiej dyskusji należałoby zastanowić się, czy uznanie danego czynu za wykroczenie jest słuszne. Podsumowując swoje rozważania, Kubicki ocenił ogłoszenie projektu prawa o wykroczeniach przed opublikowaniem projektu kodeksu karnego za działanie naruszające logiczny porządek. Zgodnie z tym porządkiem obydwa projekty powinny ukazać się co najmniej jednocześnie, po uprzednim wzajemnym ich uzgodnieniu. W przeciwnym razie przeprowadzenie dyskusji nad projektem prawa o wykroczeniach nie przyniosłaby oczekiwanych rezultatów wobec niemożności skonfrontowania jego rozwiązań z odpowiednimi przepisami projektu kodeksu karnego. Z kolei wejście w życie częściowo poprawionego w rezultacie takiej dyskusji projektu pociągnęłoby za sobą konieczność przeprowadzenia nowelizacji gruntownie zmieniającej prawo o wykroczeniach w momencie uchwalenia nowego kodeksu karnego ${ }^{50}$.

Ustosunkowując się do wysuniętych pod jej adresem uwag, Komisja podtrzymała swoje dotychczasowe stanowisko w kwestii kontynuowania prac kodyfikacyjnych prawa wykroczeń pomimo braku realnych perspektyw szybkiego uchwalenia kodeksu karnego. Powoływała się na fakt, iż prace nad tak fundamentalnym aktem prawnym jak kodeks karny „są z reguły długofalowe". W polskich realiach trwały już około 4 lat i nie przyniosły efektu w postaci ogłoszenia wersji projektu kodeksu karnego przeznaczonej do dyskusji publicznej. Powolne tempo prac kodyfikacyjnych w dziedzinie prawa karnego nie rokowało rychłego uchwalenia kodeksu karnego, natomiast stanowiło argument przemawiający za kontynuowaniem prac nad projektem prawa o wykroczeniach $^{51}$. W przeciwieństwie do zespołu opracowującego kodyfikację prawa karnego, Komisja była związana terminami zakreślonymi w uchwale Rady Ministrów dotyczącej prowadzenia i zakończenia zleconych jej prac. Dotrzymanie tych terminów wymagało szybkiego poddania projektu prawa o wykroczeniach pod publiczną dyskusję. Za wcześniejszym zakończeniem prac nad projektem prawa o wykroczeniach ,przemawiała też potrzeba równoczesnego opracowania tego prawa z przepisami opracowanego już projektu prawa o postępowaniu karno-administracyjnym”. Kolejnym argumentem przemawiającym za szybkim wejściem w życie projektu z 1961 r. było jego „szczególnie duże znaczenie dla ustawodawstwa w zakresie materialnego prawa karno-administracyjnego". Zdaniem Komisji ,istnienie podstawowych zasad części ogólnej prawa o wykroczeniach jest konieczne przy opracowy-

${ }^{50}$ L. Kubicki, op. cit., s. 501.

51 Notatka z 2 grudnia 1961 r. dotyczaca problemów wyniklych $w$ toku publicznej dyskusji nad projektem prawa o wykroczeniach, AAN Min. Spr. 1968, s. 2-3. 
waniu ustaw szczególnych z tego zakresu, gdyż będzie miało poważny wpływ na uporządkowanie i ujednolicenie systemu prawnego" 52 .

Odnosząc się do zarzutów dotyczących nieuwzględnienia w projekcie z 1961 r. podstawowych założeń części ogólnej projektu kodeksu karnego, Komisja wskazała na fakt udziału czterech jej członków w opracowaniu projektu przyszłej kodyfikacji materialnego prawa karnego. Przystępując do opracowania projektu, odrzucono zasady obowiązującego kodeksu karnego z 1932 r., które „W szeregu wypadków nie odpowiadają ani współczesnym wymaganiom życia, ani politycznym założeniom prawa socjalistycznego". Za podstawę opracowania części ogólnej projektu przyjęto rozwiązania ,dotyczące podstawowych kwestii, ustalone w pracy nad nowym kodeksem karnym”. W związku z tym Komisja korzystała z pomocy uczestniczących w pracach nad projektem kodeksu karnego L. Lernella oraz J. Bafii. Dzięki tej ,unii personalnej" oraz wykorzystaniu materiałów prawnoporównawczych ${ }^{53}$ projekt prawa o wykroczeniach miał posiadać „w zasadzie te same ujęcia dotyczące podstawowych rozwiązań, jakie przyjęto $\mathrm{w}$ pracach nad projektem nowego kodeksu karnego". Występujące nieliczne odstępstwa uzasadniano koniecznością bardziej przystępnego sformułowania przepisów prawa o wykroczeniach ,ze względu na członków kolegiów karno-administracyjnych oraz ścigających wykroczenia funkcjonariuszy MO, którzy rzadko są prawnikami" ${ }^{54}$.

W wyniku przeprowadzonej na posiedzeniu plenarnym Komisji w grudniu 1961 r. dyskusji jej członkowie jednomyślnie opowiedzieli się za utrzymaniem dotychczasowego kierunku prac kodyfikacyjnych. Stanowisko Komisji poparli zaproszeni na jej posiedzenie w charakterze ekspertów przedstawiciele doktryny prawa karnego - J. Sawicki i M. Siewierski. Podkreślano zwłaszcza zmianę stanowiska drugiego z nich, gdyż podczas debaty publicznej Siewierski kwestionował zasadność prowadzenia publicznej dyskusji nad projektem prawa wykroczeń w oderwaniu od projektu kodeksu karnego ${ }^{55}$.

VI. Podczas przeprowadzonej na początku 1962 r. debaty nad kwestiami budzącymi zastrzeżenia uczestników dyskusji środowiskowej, Komisja najwięcej uwagi poświęciła definicji wykroczenia. Reprezentujący MSW zwolennicy utrzymania dotychczasowego określania podkreślali, iż zostało ono stworzone w oparciu o koncepcję wyraźnego oddzielenia wykroczeń od prze-

${ }^{52}$ Notatka przedstawiająca różnicę poglądów w kwestiach prac na projektem prawa o wykroczeniach, AAN Min. Spr. 1967, s. 67-68.

53 W czasie prac nad projektem prawa o wykroczeniach Komisja korzystała z materiałów prawno-porównawczych w tej dziedzinie z takich krajów jak Rosyjska Federacyjna Republika Radziecka, Ukraińska Socjalistyczna Republika Radziecka, Czechosłowacja, Austria, Francja i Szwajcaria. Notatka przedstawiająca różnicę poglądów w kwestiach prac na projektem prawa o wykroczeniach, AAN Min. Spr. 1967, s. 68.

${ }^{54}$ Ibidem, s. 69.

55 Ibidem. 
stępstw. Ich zdaniem problem definicji wykroczenia wymagał rozstrzygnięcia nie tylko na gruncie teorii prawa i sporów doktrynalnych, lecz przede wszystkim na płaszczyźnie pozaprawnej. Wiązała się z nim bowiem kwestia „czy sprawcę wykroczenia ma się jak dotychczas uważać za przestępcę”. Definicję wykroczenia jako czynu zabronionego nie będącego przestępstwem uznano za słuszną ze względów społecznych, które miały przemawiać przeciwko temu „ażeby miliony sprawców wykroczeń traktować jak przestępców”. Wykorzystano także koronny argument natury ideologicznej towarzyszący prowadzonym w okresie Polski Ludowej dyskusjom naukowym, czyli fakt podobieństwa przyjętych w projekcie rozwiązań do poglądów rysujących się w nauce radzieckiej ${ }^{56}$.

Członkowie Komisji nie związani z resortem spraw wewnętrznych podkreślali potrzebę uwzględnienia wysuwanych podczas dyskusji środowiskowej licznych uwag krytycznych, w szczególności zastrzeżeń zgłaszanych przez przedstawicieli doktryny. Ich zdaniem za podstawę dalszych prac należało przyjąć zaproponowaną przez Prokuraturę Generalną kompromisową definicję wykroczenia jako czynu mniej społecznie niebezpiecznego od przestępstwa $^{57}$, który był zagrożony karami administracyjnymi. Wobec niemożności przyjęcia wspólnego stanowiska rozstrzygnięcie sporu wokół istoty wykroczenia powierzono podmiotom nadzorującym przebieg prac kodyfikacyjnych. W skierowanej na ręce Centralnej Komisji do Spraw Uporządkowania Ustawodawstwa Administracyjnego oraz ministrów sprawiedliwości i spraw wewnętrznych notatce Sekretariat Komisji przedstawił „,różnice poglądów w kwestiach dotyczących prac nad projektem prawa o wykroczeniach"58. Zajęte przez te podmioty stanowisko wyznaczyło kierunek dalszych prac kodyfikacyjnych, których efektem było wydanie drukiem w czerwcu 1962 r. drugiej wersji projektu prawa o wykroczeniach.

Ponieważ tylko część propozycji zgłoszonych przez Komisję zyskała aprobatę czynników oficjalnych, stąd kolejny projekt prawa o wykroczeniach nie różnił się zbytnio od swojego pierwowzoru. Modyfikacji uległo jedynie kilka kontrowersyjnych rozważań, przez co wprowadzone zmiany nie naruszały W sposób istotny pierwotnej konstrukcji projektu ${ }^{59}$. Odmiennie niż w pierwszej wersji sformułowano definicję wykroczenia, którym był „wszelki czyn zagrożony w czasie jego popełnienia karą administracyjną”. Przyjęcie kryterium rodzaju grożącej kary celem odróżnienia wykroczeń od innych czynów karal-

${ }^{56}$ Notatka z 2 grudnia 1961 r. dotycząca problemów wyniklych $w$ toku publicznej dyskusji nad projektem prawa o wykroczeniach, AAN Min. Spr. 1968, s. 13.

57 Notatka przedstawiająca różnice poglądów w kwestiach dotyczących prac nad projektem prawa o wykroczeniach, AAN Min. Spr. 1967, s. 72.

58 Ibidem, s. 65.

59 Najważniejszą ze zmian było wyłączenie z części szczególnej drugiej wersji projektu wykroczeń przeciwko przepisom prawa pracy w wyniku uzgodnień poczynionych z Centralną Radą Związków Zawodowych. Prawo o wykroczeniach. Projekt, Warszawa 1962, s. 149. 
nych Komisja uzasadniała tym, iż „nie udało się jej znaleźć odpowiedniej formuły odzianej w szatę artykułu" dla materialnej definicji wykroczenia. Twórcy projektu z 1962 r. konsekwentnie nawiązywali do stworzonej przez naukę socjalistyczną teorii zakładającej odrębność wykroczeń i przestępstw. Dali temu wyraz poprzez zamieszczone we wstępie do projektu opisowego sformułowania istoty wykroczenia jako czynu, który cechowało społeczne niebezpieczeństwo „niższego stopnia niż przy przestępstwie”. Z kolei w uzasadnieniu części szczególnej jako główną funkcję prawa wykroczeń wskazano ochronę karną dziedzin poddanych pieczy organów administracji państwowej. Jednocześnie podkreślono samodzielny charakter prawa wykroczeń jako działu prawa traktującego o czynach karalnych zagrożonych karami administracyjnymi ${ }^{60}$.

VII. Dalsze losy projektu prawa o wykroczeniach były ściśle powiązane z opracowaną równolegle kodyfikacją przepisów procesowych ${ }^{61}$. Krytyczna ocena rozwiązań przyszłego prawa o orzecznictwie karno-administracyjnym przez Centralną Radę Związków Zawodowych skutkowała opracowaniem w 1963 r. kolejnego projektu przepisów proceduralnych. Konsekwencją objęcia zakresem orzecznictwa karno-administracyjnego spraw z zakresu ochrony praw pracowniczych było opracowanie kolejnej - trzeciej już - wersji projektu prawa o wykroczeniach. Zawierała ona w części szczególnej obszerny rozdział dotyczący wykroczeń przeciwko przepisom prawa pracy, poza tym nie wprowadzała żadnych istotnych nowości na tle poprzednich projektów. W połowie 1963 r. projekty prawa o wykroczeniach i procedury karno-administracyjnej znajdowały się w gestii Rady Ministrów, która po dokonaniu poprawek natury redakcyjnej zamierzała skierować je do Sejmu jako rządowe projekty ustaw. Szybkie ich uchwalenie przez Sejm uznano za „sprawę bardzo pilną" ze względu na coraz bardziej odczuwalną w praktyce potrzebę skodyfikowania obszernej materii prawa karno-administracyjnego. Podkreślano także poprawność polityczną projektów, które uwzględniając aktualne wytyczne władz partyjnych i państwowych w sprawie polityki karnej dążyły do ograniczenia kar aresztu i zwiększenia roli represji ekonomicznej oraz pozakarnych środków oddziaływania wychowawczego ${ }^{62}$.

Potrzebę jak najszybszego wejścia w życie kompleksowej kodyfikacji prawa wykroczeń podkreślały nadzorujące przebieg prac kodyfikacyjnych resorty spraw wewnętrznych i sprawiedliwości. Ich wspólne stanowisko przed-

60 Ibidem, s. 172.

61 Pismo Ministra Sprawiedliwości i Ministra Spraw Wewnętrznych z dnia 29 czerwca 1962 r. w sprawie przekazania Radzie Ministrów projektu prawa o wykroczeniach $w$ wykonaniu uchwaty RMz 15 października 1959 r., AAN Min. Spr. 1966, s. 1-2.

62 Notatka dyrektora Departamentu Ustawodawczego Ministerstwa Sprawiedliwości J. Bafii z dnia 12 lipca 1963 r. w sprawie projektowanych przepisów dotyczacych prawa karno-administracyjnego (materialnego i formalnego), AAN Min. Spr. 1968, s. 294. 
stawił stojący na czele Komisji J. Bafia. Jego zdaniem projekty nie tylko „czyniły zadość rzeczywistym potrzebom jakie praktyka wysunęła", lecz także uwzględniały odrębność orzecznictwa w sprawach o wykroczenia od orzecznictwa sądów powszechnych. W szczególności kluczowa dla konstrukcji prawa o wykroczeniach zasada samoistności i odrębności części ogólnej miała stanowić „rezultat długiego procesu rozwojowego”, którego korzenie sięgały okresu międzywojennego. Pochodzące z II RP p.ow. w wielu kwestiach odsyłało do przepisów kodeksu karnego, lecz w niektórych przypadkach zawierało odrębne unormowania. Zamieszczenie w projekcie całkowicie samodzielnej części ogólnej miało być podyktowane odmiennym „charakterem czynów objętych przepisami prawa o wykroczeniach w warunkach Polski Ludowej”. Według Bafii rozwiązania przyjęte w projekcie prawa o wykroczeniach nie tylko stanowiły krok naprzód na tle obowiązującego p.o.w., lecz były także zgodne $\mathrm{z}$ „ogólnymi tendencjami występującymi w ustawodawstwie karno-administracyjnym państw socjalistycznych ${ }^{63}$.

Argumenty podnoszone przez resorty spraw wewnętrznych i sprawiedliwości zdawały się przesądzać kwestię szybkiego wejścia w życie projektów prawa o wykroczeniach i prawa o orzecznictwie karno-administracyjnym. Tymczasem nieoczekiwanie weto zgłosiły najwyższe władze partyjne, powołując się na wysuwane podczas dyskusji publicznej nad projektem kodeksu karnego postulaty przestrzegania zasady kompleksowości prac kodyfikacyjnych Za najbardziej reprezentatywne uznano stanowisko zajęte przez środowisko prawnicze, w tym przedstawicieli nauki. Ich zdaniem realizacja zasady kompleksowości w pracach nad kodyfikacją szeroko pojmowanego prawa karnego wymagała opracowania w pierwszej kolejności założeń przyszłego kodeksu karnego ${ }^{64}$. Wzgląd na synchronizację prac kodyfikacyjnych legł u podstaw podjęcia decyzji o ich wstrzymaniu do czasu opracowania kolejnego projektu kodeksu karnego, gdyż opublikowany w 1963 r. projekt zyskał krytycznie oceniony zarówno przez czynniki oficjalne, jak też uczestników publicznej debaty ${ }^{65}$. Założenia tego projektu miały stanowić punkt wyjścia wszelkich prac kodyfikacyjnych w obszarze szeroko pojmowanego prawa karnego. Oznaczało to upadek popieranej przez resorty spraw wewnętrznych i sprawiedliwości koncepcji jak najszybszego wprowadzenia w życie nowego prawa o wykroczeniach. Znajdujący się w gestii Rady Ministrów projekt z 1963 r. został odłożony do przysłowiowej szuflady, pomimo pozytywnej

${ }^{63}$ Ibidem, s. 293.

${ }^{64}$ Praktyczna realizacja tej zasady wymagała synchronizacji prac nad przyszłym kodeksem karnym z przygotowaniem następujących projektów: kodeksu postępowania karnego, prawa o wykroczeniach, prawa o orzecznictwie karno-administracyjnym oraz aktów prawnych regulujących sądownictwo społeczne i odbywanie kary pozbawienia wolności. Wstępna ocena projektu kodeksu karnego z 1963 r. w świetle dyskusji publicznej. Koreferat Wydziału Administracyjnego KC PZPR, Archiwum Akt Nowych, zespół akt KC PZPR, sygn. teczki LI/57, s. 26.

${ }^{65}$ A. Lityński, Historia prawa Polski Ludowej, Warszawa 2010, s. 146. 
oceny zarówno ze strony środowiska prawniczego, jak też praktyki orzecznictwa karno-administracyjnego. W oczekiwaniu na projekt nowego kodeksu karnego prace kodyfikacyjne materialnego prawa wykroczeniach zostały zawieszone na okres nawet kilku lat. Podjęcie takiej decyzji należy ocenić jako wyraz definitywnego zwycięstwa zasady przynależności prawa o wykroczeniach do obszaru prawa karnego ${ }^{66}$.

VIII. Opracowanie w 1966 r. kolejnego projektu kodeksu karnego, którego podstawowe założenia zostały pozytywnie ocenione przez środowisko prawnicze, postawiło na porządku dziennym kwestię wznowienia prac kodyfikacyjnych $\mathrm{w}$ dziedzinie prawa wykroczeń. Preludium prowadzonych od marca 1967 r. prac nad projektem nowego prawa o wykroczeniach stanowiło uchwalenie w dniu 17 czerwca 1966 r. Ustawy o przekazaniu niektórych drobnych wystęków jako wykroczeń do orzecznictwa karno-administracyjnego ${ }^{67}$ (ustawa o przekazaniu). Ustawa dostarczała szereg argumentów na korzyść zwolenników teorii jednolitości prawa karnego i prawa karno-administracyjnego ${ }^{68}$. Poza poddaniem właściwości kolegiów jako wykroczeń szeregu czynów stanowiących dotychczas przestępstwa (takie jak drobne zamachy na mienie społeczne, oszukiwanie nabywców, spekulacja), wprowadziła nowe, nieznane dotychczas prawu wykroczeń instytucje. Oprócz dostosowania do aktualnych potrzeb rozwiązań obowiązującej u.k.a, ustawa recypowała przepisy części ogólnej projektu kodeksu karnego dotyczące odstąpienia od wymierzania kary oraz zawieszenia wykonania zasadniczej kary aresztu. Istotnym novum było wprowadzenie możliwości przekazania przez kolegium sprawy o wykroczenie kierownikowi zakładu pracy osoby obwinionej. Powiązaniu orzecznictwa karno-administracyjnego z wymiarem sprawiedliwości służyło przyjęcie zasady, iż popełnienie przewidzianego przez ustawę czynu w warunkach recydywy skutkuje uznaniem go za przestępstwo podlegające właściwości sądów ${ }^{69}$. Stanowiąca ważny krok w kierunku harmonizacji przepisów prawa wykroczeń i prawa karnego ustawa o przekazaniu została opracowana pod kątem przyszłej kodyfikacji materialnego prawa wykroczeń. Z założenia tymczasowe rozwiązania miały zostać w całości przejęte przez przyszłe prawo o wykroczeniach ${ }^{70}$.

Zadanie jego stworzenia powierzono utworzonej na mocy wspólnego zarządzenia ministrów spraw wewnętrznych i sprawiedliwości z dnia 28 lutego

${ }^{66}$ J. Jakubowska-Hara, op. cit., s. 58.

${ }^{67}$ Dz. U. nr 23, poz. 149.

68 W.F. Dąbrowski, Nowe aspekty orzecznictwa karno-administracyjnego, „Ruch Prawniczy, Ekonomiczny i Socjologiczny" 1967, nr 1, s. 94.

${ }^{69}$ Informacja dyrektora DSA MSW Z. Orlowskiego o projekcie prawa o wykroczeniach z 1967 r., IPN BU MSW II 514, część II, s. 438.

70 D. Egierska-Pakuła, Projekt prawa o wykroczeniach, „ZKA” 1967, nr 5, s. 14-15. 
1967 r. Komisji do opracowania Projektu Prawa o Wykroczeniach ${ }^{71}$ (zwana dalej Komisją). Potrzebę utworzenia Komisji uzasadniano zaawansowaniem prac nad projektem kodeksu karnego, do którego założeń miało szeroko nawiązywać przyszłe prawo o wykroczeniach. Fakt występowania szeregu powiązań pomiędzy tymi dwoma aktami prawnymi stanowił argument przemawiający za jednoczesnym wprowadzeniem w życie kompleksowych rozwiązań dotyczących przestępstw i wykroczeń. Skład Komisji powielał schematy wypróbowane podczas pierwszej fazy prac kodyfikacyjnych, gdyż funkcję przewodniczącego pełnił delegowany przez resort sprawiedliwości J. Bafia. Jego zastępcą został Z. Orłowski, który po objęciu urzędu ministra spraw wewnętrznych przez M. Moczara awansował na stanowisko dyrektora DSA MSW. Uwzględniono udział w pracach nad przyszłym prawem o wykroczeniach zarówno przedstawicieli zainteresowanych resortów, jak też reprezentujących ośrodki akademickie teoretyków prawa karnego i prawa administracyjnego. Założenie traktowania prawa o wykroczeniach jako części składowej szeroko pojmowanego prawa karnego skutkowało powołaniem w skład komisji dwóch przedstawicieli Katedry Prawa Karnego UW - I. Andrejewa oraz A. Gubińskiego. Nauki administracyjne reprezentował delegowany do pracy w Komisji również przez UW J. Starościak ${ }^{72}$.

W porównaniu ze składem poprzedniej komisji (obradującej w latach 1960-1963) widoczna była przewaga przedstawicieli nauki prawa karnego. Spośród nich szczególny wpływ na przebieg prac kodyfikacyjnych wywarł A. Gubiński. Jako czołowy teoretyk prawa karno-administracyjnego drugiej połowy lat sześćdziesiątych Gubiński odgrywał pierwszoplanową rolę w procesie przywracania prawa wykroczeń do programu nauczania studiów prawniczych oraz pobudzenia zainteresowania nauki tą dziedziną prawa. Został kierownikiem pierwszego w powojennej Polsce Zakładu Prawa Karno-Administracyjnego, który funkcjonował w strukturach Katedry Prawa Karnego UW. Wydany w 1968 r. podręcznik jego autorstwa ${ }^{73}$ stanowił pierwszą próbę teoretycznej analizy systemu polskiego prawa wykroczeń pod rządzami u.k.a.. Wielokrotnie wznawiany, przez szereg lat stanowił podstawowe źródło wiedzy dla wszystkich interesujących się poruszoną w nim problematyką ${ }^{74}$. Gubiński wyraźnie stał na gruncie teorii o jednorodności gatunkowej przestępstw i wykroczeń, które różniły się od siebie stopniem społecznego niebezpieczeństwa. Podkreślał przy tym fakt przynależności prawa karno-admini-

${ }^{71}$ Zarządzenie Ministrów Spraw Wewnętrznych i Sprawiedliwości z dnia 28 lutego 1967 r. o powołaniu Komisji do opracowania Projektu Prawa o Wykroczeniach (Dz. U. MSW nr 3, poz. 8). IPN BU MSW II 24985, s. 1-3.

72 Ibidem, s. 2.

73 Prawo karno-administracyjne, Warszawa 1967. Następnie wielokrotnie wydawany jako Prawo wykroczeń.

${ }^{74}$ L. Falandysz, Arnold Gubiński (1916-1997), „Studia Iuridica” XXXIV/1997, s. 220. 
stracyjnego do obszaru prawa karno-sądowego ${ }^{75}$. Do poglądów Gubińskiego nawiązywały kolejne opracowania poświęcone problematyce prawa karno-administracyjnego, które coraz liczniej ukazywały się wraz z postępami prac kodyfikacyjnych $^{76}$. Działalność Gubińskiego niewątpliwie przyczyniła się do przywrócenia należnego miejsca zapomnianej niemal całkowicie dziedzinie prawa wykroczeń, która stała się przedmiotem dyskusji i sporów naukowych.

IX. Przystępując do prac nad nowym projektem prawa o wykroczeniach Komisja musiała rozwiązać problem definicji wykroczenia oraz sposobu przeprowadzenia recepcji rozwiązań części ogólnej prawa karnego. Poszukując optymalnego określenia wykroczenia rozważano uzupełnienie definicji materialnej o kryterium formalne, uwzględniające wysokość grożących kar. Za takim rozwiązaniem przemawiać miało przekazanie do orzecznictwa kolegiów szeregu dotychczasowych występków jako czynów cechujących się znikomym ładunkiem społecznego niebezpieczeństwa. Natomiast problem recepcji przepisów części ogólnej projektu prawa karnego zamierzano rozstrzygnąć albo w drodze powoływania się na odpowiednie artykuły kodeksu karnego lub poprzez przytoczenie w pełnym brzmieniu stosownych regulacji ${ }^{77}$.

Ogłoszony drukiem w lipcu 1967 r. projekt prawa o wykroczeniach ${ }^{78}$ (projekt z 1967 r.) został odpowiednio zharmonizowany z przygotowywanym nowym kodeksem karnym. W całości przejmował także rozwiązania wprowadzone ustawą o przekazaniu. Kluczowa dla ponoszenia odpowiedzialności karno-administracyjnej kwestia definicji wykroczenia została rozstrzygnięta przez Komisję adekwatnie do projektu kodeksu karnego. Jako warunek pociągnięcia do odpowiedzialności karno-administracyjnej projekt z 1967 r. przewidywał popełnienie czynu społecznie niebezpiecznego, zabronionego pod groźbą kary przez obowiązująca ustawę, który jednocześnie nie był przestępstwem $^{79}$. Wobec zamieszczenia sformułowania o podleganiu odpowiedzialności karno-administracyjnej art. 1 projektu nie operował wprost terminem wykroczenie, co należy ocenić negatywnie z punktu widzenia techniki legislacyjnej. W sposób nie budzący wątpliwości twórcy projektu z 1967 r. rozstrzygnęli sporny problem wzajemnych relacji pomiędzy wykroczeniem a przestępstwem. Zdecydowane podkreślenie odrębności tych dwóch rodza-

75 A. Gubiński, Prawo karno-administracyjne. Wykroczenia, Warszawa 1967, s. 5.

${ }^{76}$ Kolejnym opracowaniem teoretycznym poświęconym tym razem problematyce orzecznictwa k-a była monografia W. F. Dąbrowskiego, Orzecznictwo karno-administracyjne w PRL, Poznań 1967.

77 Notatka DSA MSW w sprawie kwestii wstępnych wymagających zajęcia stanowiska w zwiazku ze wznowieniem prac kodyfikacyjnych materialnego prawa wykroczeń, IPN BU MSW II 24985, s. 4.

78 Prawo o wykroczeniach. Projekt, Warszawa 1967.

${ }^{79} \mathrm{~W}$ myśl art. 1 projektu „Odpowiedzialności karno-administracyjnej podlega ten tylko, kto dopuszcza się czynu społecznie niebezpiecznego, nie będącego przestępstwem, zabronionego pod groźbą kary przez ustawę obowiązującą w czasie jego popełnienia". 
jów czynów karalnych uzasadniano powszechnie akceptowanym przez opinię społeczną poglądem, iż sprawca wykroczenia nie jest przestępcą ${ }^{80}$. Stojąc na gruncie odrębności wykroczeń od przestępstw Komisja przyjęła założenie całkowicie samodzielnego charakteru części ogólnej projektu, rezygnując z jakichkolwiek odesłań do przepisów kodeksu karnego. Recypowane instytucje części ogólnej prawa karnego zostały odpowiednio zmodyfikowane z uwzględnieniem charakteru wykroczeń jako czynów karalnych różniących się od przestępstw stopniem społecznego niebezpieczeństwa czynu ${ }^{81}$.

Wprawdzie nieudolnie sformułowana definicja wykroczenia mogłaby sugerować przyjęcie przez twórców projektu założenia o całkowitej odrębności wykroczeń od przestępstw, lecz w rzeczywistości chodziło im o podkreślenie specyfiki wykroczeń jako „czynów małej wagi w porównaniu z przestępstwami" " 2 . W taki sposób intencje członków Komisji odczytywali przedstawiciele nauki, w tym zwolennik teorii o jednolitości rodzajowej wykroczeń i przestępstw E. Iserzon. Jego zdaniem klamrą łączącą wykroczenia i przestępstwa było społeczne niebezpieczeństwo czynu, którego waga decydowała o charakterze danego czynu karalnego. Czyny cechujące się dużym stopniem społecznego niebezpieczeństwa stanowiły przestępstwa w rozumieniu projektu kodeksu karnego, obejmującego tylko zbrodnie i występki. Z kolei czyny karalne, których ładunek społecznego niebezpieczeństwa był mały lub nawet znikomy, zostały zamieszczone w projekcie z 1967 r. jako wykroczenia ${ }^{83}$. Na jednolitą treść materialną wykroczeń i przestępstw wskazywał także reprezentujący UAM administratywista W. Dąbrowski. Jego zdaniem u podstaw podziału czynów karalnych na przestępstwa karane sądownie i rozpatrywane w trybie karno-administracyjnym wykroczenia leżały względy natury konwencjonalnej ${ }^{84}$.

X. Podejmowane przez przedstawicieli doktryny próby przedstawienia w pozytywnym świetle zawartej w projekcie z 1967 r. definicji wykroczenia nie przekonały uczestników szerokiej dyskusji środowiskowej. Pozytywnie oceniono jedynie fakt oparcia tej definicji na zaczerpniętym z projektu kodeksu karnego kryterium materialnym w postaci społecznego niebezpieczeństwa czynu. Sam sposób sformułowania definicji uznano za dalece niefortunny, gdyż nie wynikało z niego wprost, czym jest wykroczenie. Oznaczało to konieczność tworzenia definicji wykroczenia w drodze dedukcji, z uwzględnieniem zawartych $\mathrm{w}$ art. 1 projektu cech charakterystycznych tej grupy

80 D. Egierska-Pakuła, op. cit. s. 18.

81 Ibidem, s. 13-14.

82 Prawo o wykroczeniach. Projekt, Warszawa 1967, s. 6.

83 E. Iserzon, Kolegia karno-administracyjne $w$ systemie organów państwowych, „Studia Prawnicze" 1969, z. 21, s. 98.

84 W.F. Dąbrowski, Nowe aspekty..., s. 94-95. 
czynów karalnych. Sceptycznie przyjęto również fakt zamieszczenia zwrotu o podleganiu sprawcy wykroczenia odpowiedzialności karno-administracyjnej. Miało to prowadzić do niepotrzebnego przeniesienia zagadnień materialnego prawa wykroczeń na płaszczyznę procesową. Uznania uczestników dyskusji nie zyskała także próba definitywnego rozstrzygnięcia przez Komisję długoletniego sporu naukowego w przedmiocie wzajemnych relacji pomiędzy wykroczeniem a przestępstwem. Zdaniem uczestników dyskusji nad projektem z 1967 r. zamieszczenie tego rodzaju negatywnego stwierdzenia miało wyłącznie walor teoretyczny. Nie zawierało bowiem istotnych z punktu widzenia praktyki orzecznictwa karno-administracyjnego kryteriów ułatwiających rozgraniczenie wykroczenia od przestępstwa ${ }^{85}$.

$\mathrm{Na}$ kanwie poczynionych uwag krytycznych przedstawiciele nauki prawa z A. Gubińskim na czele, opowiadali się za uzupełnieniem materialnego określenia wykroczenia kryterium formalnym. Wzorem obowiązującego p.ow. kryterium to wskazywałoby górne granice kar grożących sprawcy wykroczenia. Wprowadzenie elementu zagrożenia karą umożliwiłoby organom ścigania i kolegiom łatwe ustalenie, czy dany czyn karalny należy do kategorii wykroczeń. Kolejnej korzyści upatrywano we wprowadzeniu zwrotu 'odpowiedzialność za wykroczenie' w miejsce niefortunnego sformułowania o odpowiedzialności karno-administracyjnej sprawcy czynu społecznie niebezpiecznego. Uznając materialne określenie czynu karalnego za trwały dorobek doktryny socjalistycznej nauki prawa karnego, nie wysuwano w zasadzie żądań powrotu do formalnej definicji wykroczenia. W towarzyszącym dyskusji nad projektem z 1967 r. sporze odnośnie do kształtu materialnej definicji wykroczenia ścierały się dwie grupy poglądów. $Z$ jednej strony wskazywano na potrzebę podkreślenia różnicy pomiędzy wykroczeniem a przestępstwem od strony ich ujemnego ładunku społecznego. Przeciwni temu rozwiązaniu byli zwolennicy sprowadzenia przestępstw i wykroczeń do wspólnego mianownika $\mathrm{w}$ postaci społecznego niebezpieczeństwa czynu. Za przyjęciem wspólnego mianownika przemawiać miała bliskość niektórych występków i wykroczeń, szczególnie widoczna w przypadku drobnych występków przekazanych do orzecznictwa karno-administracyjnego. Ich zdaniem dla praktycznego odróżnienia wykroczeń od przestępstw w zupełności wystarczało wzbogacenie zawartej w projekcie p.ow. materialnej definicji o kryterium formalne wskazujące dopuszczalne granice karalności. Niektórzy uczestnicy dyskusji wysuwali w związku z tym postulat wyraźnego stwierdzenia, iż czyn karalny w przypadku braku społecznego niebezpieczeństwa nie stanowi wykroczenia ${ }^{86}$.

${ }^{85}$ M. Siewierski, Nowy projekt prawa o wykroczeniach, „PiŻ” 1967, nr 22, s. 3.

${ }^{86}$ A. Gubiński, Niektóre zagadnienia kodyfikacji prawa o wykroczeniach, „PiP” 1968, nr 2, s. 216-217. 
XI. Z wyjątkiem tej ostatniej uwagi Komisja uznała zasadność zastrzeżeń wysuwanych pod adresem zamieszczonej w projekcie z 1967 r. definicji wykroczenia. Sporządzona w oparciu o wyniki dyskusji środowiskowej robocza wersja projektu prawa o wykroczeniach z marca $1968 \mathrm{r}^{87}$ (projekt z $1968 \mathrm{r}$.), zawierała mieszaną definicję wykroczenia. W świetle tej definicji wykroczenie było czynem społecznie niebezpiecznym, zagrożonym karami przez ustawę obowiązującą w czasie jego popełnienia. Sprawcy wykroczenia groziły następujące kary: areszt zasadniczy w wymiarze do 3 miesięcy, ograniczenie wolności do 3 miesięcy, grzywna do 5000 złotych lub nagana. Projekt uwzględniał zarówno formalny, jak i materialny charakter wykroczenia, stąd dla uznania danego czynu zabronionego za wykroczenie niezbędne było łączne występowanie obydwu tych elementów. Cechą formalną, która odgraniczała wykroczenie od przestępstwa, było zagrożenie określonymi w ustawie karami. Oprócz wytyczenia granicy pomiędzy wykroczeniem a przestępstwem, zamieszczenie definicji formalnej służyło podkreśleniu obowiązywania na gruncie prawa wykroczeń zasady nullum crimen sine lege. Podobnie jak w przypadku przestępstw materialną cechę wykroczenia stanowiło społeczne niebezpieczeństwo czynu ${ }^{88}$. W zgodnej opinii członków Komisji ograniczenie się wyłącznie do cechy formalnej stałoby w sprzeczności z zasadami socjalistycznego prawa karnego. Pominięcie elementu materialnego oznaczałoby konieczność kwalifikowania jako wykroczenia wszelkich czynów wypełniających ustawowe znamiona czynu zabronionego, chociażby nie zawierały one społecznie ujemnej treści ${ }^{89}$.

XII. Zdaniem Komisji tożsamość wykroczeń i przestępstw wynikała z faktu, iż prawo o wykroczeniach stanowiło w sensie społecznym dopełnienie kodeksu karnego. Podobnie jak kodeks karny regulowało zasady odpowiedzialności i karania oraz określało czyny zakazane lub nakazane pod groźbą kary. O ile jednak kodeks karny zajmował się walką z zamachami godzącymi dotkliwie w interesy państwa, społeczeństwa oraz prawa i interesy jednostek, to prawo o wykroczeniach służyło karaniu drobniejszych, lecz przez swoją masowość nader dokuczliwych naruszeń porządku prawnego. Prawo o wykroczeniach nie dotyczyło wyłącznie karania naruszeń o charakterze ogólnokryminalnym, gdyż zawierało liczne stany faktyczne związane z działalnością administracji państwowej. Znaczna część przewidzianych projekcie wykroczeń miała bowiem rodowód administracyjny, a karanie ich sprawców służyło zabezpieczeniu realizacji zadań stojących przed organami administracji. Argument ten przyjęto jako uzasadnienie nadania samodzielnego cha-

87 Prawo o wykroczeniach. Projekt roboczy z marca 1968. IPN BU MSW II 514, część II.

${ }^{88}$ Uzasadnienie projektu prawa o wykroczeniach z marca 1968 r., IPN BU MSW II 514, część II, s. 57.

89 E. Popek, Wykroczenie - czyn społecznie niebezpieczny, „ZKA” 1969, nr 6, s. 14-16. 
rakteru części ogólnej przyszłego prawa o wykroczeniach. Jej poszczególne rozwiązania posiadały uproszczony charakter na tle przepisów części ogólnej kodeksu karnego. Wobec sprawców wykroczeń miały zastosowanie podstawowe zasady dotyczące odpowiedzialności karnej ${ }^{90}$, takie same były stadia i formy popełnienia czynu ${ }^{91}$ oraz ustawowe okoliczności wyłączające karną bezprawność czynu. Jednakże z uwagi na specyfikę wykroczeń część ogólna projektu z 1968 r. nie zawierała pewnych rozwiązań występujących w projekcie kodeksu karnego, gdyż zostały one uznane za niepotrzebne ${ }^{92}$. Niektóre zaś zasady odpowiedzialności i karania zostały zmodyfikowane - z uwagi na charakter czynów - w stosunku do rozwiązań przyjętych w kodeksie karnym. Przykładem było odmienne uregulowanie kwestii odpowiedzialności za usiłowanie, podżeganie i pomocnictwo. Zdaniem twórców projektu założenie samodzielnego charakteru jego części ogólnej było uzasadnione nie tylko względami natury merytorycznej, lecz także praktycznej. Prawo o wykroczeniach traktowano bowiem w kategoriach instrumentu służącego zwalczaniu drobnych naruszeń prawa, których społeczne niebezpieczeństwo wyrażało się w powszechności występowania ${ }^{93}$.

XIII. Podczas dyskusji publicznej przedstawiciele nauki przychylnie ocenili konstrukcję części ogólnej projektu z 1967 r. , której samoistny charakter miał podkreślać specyfikę prawa wykroczeń jako samodzielnego działu szeroko pojmowanego prawa karnego. Ich zastrzeżenia budziło pominięcie przewidzianej w projekcie kodeksu karnego kary ograniczenia wolności oraz sposób redakcji niektórych przepisów części ogólnej projektu. U podstaw rezygnacji z kary ograniczenia wolności legły negatywne doświadczenia wyniesione z praktyki stosowania w latach pięćdziesiątych kary pracy poprawczej ${ }^{94}$. W obawie przez kolejnym niepowodzeniem większość członków Komisji

${ }^{90}$ Były to zasada nullum crimen sine lege, nulla poena sine lege oraz winy jako podstawy odpowiedzialności sprawcy wykroczenia. Uzasadnienie projektu prawa o wykroczeniach z marca 1968 r., IPN BU MSW II 514, część II, s. 351.

${ }^{91}$ Odmienne były zasady ponoszenia odpowiedzialności, gdyż na gruncie prawa wykroczeń karalność form stadialnych i zjawiskowych miała miejsce tylko, gdy wyraźnie tak stanowił przepis części szczególnej projektu. Uzasadnienie projektu prawa o wykroczeniach z marca $1968 \mathrm{r}$., IPN BU MSW II 514, część II, s. 352.

92 Uwaga ta dotyczyła przepisów części ogólnej prawa karnego regulujących odpowiedzialność za czyn popełniony za granicą, instytucji środków zabezpieczających oraz przedterminowego zwolnienia. Uzasadnienie projektu prawa o wykroczeniach z marca 1968 r. IPN BU MSW II 514, część II, s. 351.

${ }^{93}$ Ibidem.

${ }^{94}$ Istota wprowadzonej przez u.o.k.a. kary pracy poprawczej polegała na obowiązku wykonywania przez osobę ukaraną dozorowanej pracy na cele publiczne. W stosunku od osób zatrudnionych w uspołecznionych zakładach pracy przewidziano potrącenie na poczet kary $20 \%$ wynagrodzenia miesięcznie. Szerzej na temat istoty kary pracy poprawczej oraz praktyki jej stosowania M. Łysko, Kara pracy poprawczej w orzecznictwie karno-administracyjnym Polski Ludowej, w: „Miscellanea Historico-Iuridica”, t. VI, red. A. Lityński, P. Fiedorczyk, Białystok 2008. 
asekuracyjnie twierdziła, iż zawarte w projekcie kary i środki oddziaływania społecznego ,są wystarczające dla skutecznego karania i wychowywania sprawców wykroczeń”. W rzeczywistości katalog kar zasadniczych był dosyć ubogi, gdyż obok znanych przedwojennemu p.ow. kar aresztu i grzywny, zawierał jedynie wyrażającą potępienie moralne sprawcy wykroczenia naganę. Negatywnego stosunku Komisji do kary ograniczenia wolności nie podzielał uczestniczący w jej pracach A. Gubiński oraz Katedry Prawa Karnego w Toruniu i we Wrocławiu ${ }^{95}$. Ich zdaniem pominięcie kary ograniczenia wolności stanowiło poważny brak projektu. Kara ta mogłaby z powodzeniem zastąpić krótkoterminowe kary aresztu, które ze względów penitencjarnych okazały się niecelowe i nieprzydatne z wychowawczego punktu widzenia. Zwolennicy kary ograniczenia wolności podkreślali jej znaczenie dla dalszego ograniczenia stosowania aresztu zasadniczego, wymierzonego w latach sześćdziesiątych przeciętnie wobec około 1\% ogółu ukaranych przez kolegia. Wśród skazanych znajdował się spory odsetek osób wykazujących tzw. „wstręt do pracy”, które uchylały się od podjęcia stałej pracy zarobkowej. W świetle zawartych w projekcie z 1967 r. dyrektyw wymiaru kary jedynym środkiem orzekanym w praktyce wobec tej grupy sprawców wykroczeń pozostawała grzywna. Jednakże wobec braku regularnych dochodów orzeczone przez kolegia grzywny podlegały zamianie na areszt zastępczy, a przecież projekt z $1967 \mathrm{r}$. stał na gruncie odchodzenia od stosowania krótkoterminowych kar izolacyjnych ${ }^{96}$. $\mathrm{Na}$ tle kar aresztu i grzywny, których orzekanie oznaczało de facto izolowanie osób niepracujących od społeczeństwa i dalszą demoralizację spowodowaną pobytem w areszcie, kara ograniczenia wolności posiadała walor wychowawczego oddziaływania poprzez pracę. Zalety tej kary dostrzegli twórcy projektu kodeksu karnego, co zdaniem uczestników publicznej dyskusji przemawiało za jej uwzględnieniem w przyszłym prawie o wykroczeniach. Wprowadzenie tej kary uznano za wskazane z punktu widzenia wzajemnej harmonizacji katalogów kar w obydwu projektach. Podkreślano, iż wyznaczony przez projekt kodeksu karnego kierunek reformy ustawodawstwa powinien obowiązywać również na gruncie wykroczeń ${ }^{97}$.

Postulaty zgłaszane przez doktrynę wpłynęły na zmianę stanowiska Komisji. Większość jej członków uznała, iż ewentualne trudności związane z praktyczną realizacją kary ograniczenia na wolności nie mogły przesłonić walorów ogólno-prewencyjnych ani wychowawczego wpływu tej kary na sprawców wykroczeń. Katalog kar zasadniczych projektu w redakcji z 1968 r. uwzględniał karę ograniczenia w ogólnym kształcie prawie nie różniącym się od ujęcia projektu kodeksu karnego. Karę tę przewidziano w sankcji 28 artykułów części szczególnej projektu, gdzie występowała alternatywnie obok

95 D. Egierska, Zmiany w projekcie prawa o wykroczeniach, „ZKA” 1969, nr 1, s. 20.

96 Ibidem, s. 21.

${ }^{97}$ A. Gubiński, Niektóre zagadnienia..., s. 223. 
kar aresztu lub grzywny. Wymiar kary ograniczenia wolności wynosił od jednego do trzech miesięcy. Podczas jej odbywania osoba ukarana nie mogła bez zgody organu orzekającego zmienić miejsca stałego pobytu, miała obowiązek wykonywania pracy wskazanej przez organ orzekający oraz udzielania wyjaśnień dotyczących przebiegu kary ${ }^{98}$.

Ponadto Komisja uwzględniła uwagi w przedmiocie zakresu karalności pomocnictwa, która w projekcie z 1967 r. obejmowała nie tylko działanie bezpośrednie, lecz także zamiar ewentualny. Przychylając się do poglądu reprezentującego UMCS karnisty H. Rajmana, Komisja uznała takie rozwiązanie za zbyt daleko posunięty przejaw karalności. Nowa redakcja przepisu dotyczącego pomocnictwa obejmowała jedynie działanie sprawcy w formie zamiaru bezpośredniego ${ }^{99}$. Zmianie uległ także przepis części ogólnej projektu określający miejsce popełnienia wykroczenia, który zdaniem uczestników dyskusji był sformułowany zbyt ogólnikowo, a przez to mało przydatny dla potrzeb praktyki. Przedstawiciele nauki postulowali rezygnację z mało precyzyjnego stwierdzenia o odpowiedzialności za wykroczenia popełnione na terytorium PRL, na rzecz wprowadzenia definicji tego terminu pojęcia z uwzględnieniem obszaru polskich statków wodnych i powietrznych. Zwrócono także uwagę na sprzeczność ogólnikowych rozwiązań projektu z regulacjami dotyczącymi odpowiedzialności za popełnione za granicą wykroczenia przeciwko prawu lotniczemu. Natomiast autorytet $\mathrm{w}$ dziedzinie prawa karnego W. Wolter wskazując na samodzielny charakter części ogólnej projektu, wysunął postulat określenia czasu oraz miejsca popełnienia wykroczenia $^{100}$.

Po rozważeniu otrzymanych uwag Komisja rozszerzyła zakres terytorialny obowiązywania projektu o polskie statki wodne i powietrzne oraz określiła zasady ponoszenia odpowiedzialności za wykroczenia popełnione przez obywateli polskich za granicą. Miało to miejsce w sytuacji, gdy przepis szczególny przewidywał tego rodzaju odpowiedzialność. Nawiązując do postulatu W. Woltera, wprowadzono nowy artykuł określający wzorem projektu kodeksu karnego miejsce i czas popełnienia wykroczenia ${ }^{101}$.

XIV. Roboczy projekt prawa o wykroczeniach z marca 1968 r. uległ częściowej modyfikacji pod wpływem postulatów zgłaszanych przez poszczególne ministerstwa, które postulowały nowe ujęcie stanów faktycznych wykroczeń związanych z zakresem ich działalności. Stworzona przy współudziale nauki prawa konstrukcja części ogólnej oraz jej poszczególne rozwiązania nie

98 A. Gubiński, Kary zasadnicze w projekcie prawa o wykroczeniach, „ZKA” 1969, nr 2, s. $38-41$.

99 A. Gubiński, Niektóre zagadnienia..., s. 220.

100 D. Egierska, op. cit., s. 16-17.

101 Ibidem, s. 16. 
zostały zakwestionowana przez Kolegium Ministerstwa Spraw Wewnętrznych. Podczas odbywających się drugiej połowie 1968 r. posiedzeń kierownictwo resortu definitywnie rozstrzygnęło problemy budzące kontrowersję wśród uczestników dyskusji publicznej. Kierownictwo resortu opowiedziało się za utrzymaniem kary ograniczenia wolności oraz pod wpływem argumentacji A. Gubińskiego krytycznie oceniło wysuwany przez praktykę postulat rezygnacji z nagany jako kary zasadniczej. Oponenci podniesienia nagany do rangi kary zasadniczej postulowali utrzymanie przewidzianej w u.k.a zasady orzekania nagany w razie nadzwyczajnego złagodzenia kary. Dopuszczali jedynie rozszerzenie zakresu stosowania nagany na pozostałe przypadki, w których byłoby to wskazane z uwagi na okoliczności czynu lub osobowość sprawcy. Przeciwnego zdania byli przedstawiciele nauki, zgodnie opowiadający się za utrzymaniem nagany w katalogu kar zasadniczych z uwagi na znaczenie czynnika moralnego w orzecznictwie karno-administracyjnym. Czynnik ten miał pełnić istotną rolę $\mathrm{w}$ procesie wdrażania sprawców drobnych wykroczeń do poszanowania prawa i zasad współżycia społecznego. Zdaniem A. Gubińskiego wprowadzenie nagany do katalogu kar zasadniczych stwarzało kolegiom możliwość elastycznego reagowania w zależności od wagi popełnionego wykroczenia i osobowości sprawcy. Charakterystyczne dla prawa wykroczeń rozwiązanie stanowiło odpowiednik funkcjonującej na gruncie procedury karnej instytucji warunkowego umorzenia postępowania ze względu na znikomą szkodliwość społeczną czynu ${ }^{102}$.

Po wprowadzeniu przez Komisję autopoprawek wersja robocza projektu z marca 1968 r. została przedłożona połączonemu kolegium Ministerstwa Spraw Wewnętrznych oraz ministerstwa sprawiedliwości celem ostatecznego zatwierdzenia. Po uzyskaniu akceptacji kierownictwa resortów nadzorujących przebieg prac kodyfikacyjnych, projekt przyszłego prawa o wykroczeniach został poddany konsultacjom na szczeblu międzyresortowym ${ }^{103}$. Po wprowadzeniu drobnych poprawek o charakterze redakcyjnym projekt został przekazany Radzie Ministrów w celu rozpatrzenia. Wraz z projektem prawa o wykroczeniach dyrektor DSA MSW Z. Orłowski przesłał Radzie Ministrów w marcu 1969 r. pozostałe projekty składające się na całościową kodyfikację prawa wykroczeń Polski Ludowej. Były to opracowywane przez działającą równolegle komisję projekty kodeksu postępowania w sprawach o wykroczenia oraz ustawy o ustroju kolegiów do spraw wykroczeń ${ }^{104}$. W tym momencie powołana $\mathrm{z}$ inicjatywy ministrów spraw wewnętrznych i sprawiedliwości

102 A. Gubiński, Kary zasadnicze..., s. 44.

${ }^{103}$ Pismo dyrektora DSA MSW Z. Orlowskiego z dnia 31 października 1969 r. do Komendanta Głównego MO Franciszka Jóźwiaka w sprawie projektu prawa o wykroczeniach, IPN BU MSW 89/146, s. 4.

104 J. Lewiński, Kodyfikacja przepisów o postępowaniu w sprawach o wykroczenia, „NP” 1969, nr 6, s. 916. 
w 1967 r. komisja uległa rozwiązaniu, gdyż pomyślnie wykonała powierzone jej zadanie opracowania nowego prawa o wykroczeniach ${ }^{105}$.

Zgłoszone przez Radę Ministrów drobne uwagi natury redakcyjnej zostały uwzględnione w ostatecznej wersji projektu, która ukazała się drukiem w październiku 1969 r. ${ }^{106} 21$ listopada 1969 r. projekty składające się na kompleksową kodyfikację prawa wykroczeń zostały w praktycznie niezmienionej postaci zatwierdzone przez Prezydium Rządu jako rządowe projekty ustaw ${ }^{107}$. Zgodnie z uchwałą Prezydium Rządu projekty miały wejść w życie w ciągu 6 miesięcy od daty ich uchwalenia, którą początkowo wyznaczono na koniec grudnia 1969 r. Potrzebę szybkiego skierowania projektów pod obrady sejmu uzasadniano faktem ich przynależności do obszaru prawa karnego, którego trzon stanowił uchwalony 19 kwietnia 1969 r. kodeks karny ${ }^{108}$. Nowy kodeks karny wchodził w życie z początkiem 1970 r., a stanowiące jego uzupełnienie przyszłe prawa o wykroczeniach miałoby obowiązywać od lipca tegoż $\mathrm{roku}^{109}$. Ostatecznie odstąpiono od koncepcji jak najszybszego skierowania projektu pod obrady Sejmu, gdyż czynniki oficjalne podjęły decyzję o przeprowadzeniu zakrojonej na szeroką skalę dyskusji społecznej nad podstawowymi założeniami przyszłej kodyfikacji materialnego prawa wykroczeń. Wydany ponownie drukiem w $1970 \mathrm{r}$. i rozprowadzany w drodze sprzedaży projekt prawa o wykroczeniach ${ }^{110}$ (projekt z 1970 r.) miał być przedmiotem konsultacji społecznych, których organizację powierzono wojewódzkim zespołom poselskim. Debatę nad projektem w środowisku prawniczych miały zorganizować terenowe ogniwa Zrzeszenia Prawników Polskich, przewidziano także dyskusję na łamach prasy prawniczej ${ }^{111}$.

XV. Przedstawiciele nauki ocenili projekt z 1970 r. jako zwieńczenie procesu stopniowego oddalania się prawa wykroczeń od prawa administracyjnego na rzecz bliskich powiązań z systemem prawa karnego. W opinii J. Sku-

105 D. Egierska, op. cit., s. 13.

106 Prawo o wykroczeniach. Projekt, Warszawa - październik 1969, IPN BU MSW II 89/146.

107 Pismo Dyrektora DSA MSW Z. Orlowskiego z dnia 15 grudnia 1969 r. w sprawie możliwości wprowadzenia do prawa o wykroczeniach przepisu umożliwiającego ściganie na drodze k-a naruszeń zakazu fotografowania obiektów wojskowych i gospodarczych, IPN BU MSW II 514, s. 272.

108 Dz. U. nr 13, poz. 94.

109 Niektóre przepisy części szczególnej projektu miałyby wejść w życie równocześnie z kodeksem karnym, gdyż dotyczy wykroczeń powstałych z przekształcenia przewidzianych w kodeksie karnym z 1932 r. występków. Przedwojenny kodeks karny tracił moc obowiązującą w dniu wejścia kodeksu karnego z 1969 r. który już w ogóle nie przewidywał karalności dotychczasowych występków z racji przekazania ich do orzecznictwa k-a. W związku z tym obawiano się, że po dniu 1 stycznia 1970 r. powstałaby w tym zakresie luka prowadząca do niezamierzonej depenalizacji. Notatka w sprawie realizacji postanowień Prezydium Rządu z dn. 21 XI 1969 r. odnośnie kodyfikacji przepisów dotyczących wykroczeń, IPN BU MSW II 514, część II, s. 260.

110 Prawo o wykroczeniach. Projekt, Warszawa 1970.

111 Projekt kodeksu wykroczeń w Sejmie, „NP” 1971, nr 7-8, s. 995. 
pińskiego przyszła kodyfikacja materialnego prawa wykroczeń znajdowała się „,bez porównania bliżej prawa karnego” niż obowiązujące p.ow. Fakt ten miał stanowić nieuniknioną konsekwencję tzw. „kryminalizacji” prawa karno-administracyjnego, czyli rozszerzenia katalogu wykroczeń o czyny typowo kryminalne. Twórcy projektu z 1970 r. nie tylko utrzymali stan prawny stworzony ustawą o przekazaniu, lecz przejęli kolejną poważną grupę występków do kategorii wykroczeń. Ponadto projekt przewidywał karalność pewnych czynów dotychczas nie podlegających penalizacji, których stany faktyczne nie wykazywały jakiegokolwiek związku z bieżąca działalnością administracji państwowej. Pierwszym z nich było natarczywe zaczepianie potencjalnych klientów przez oferujące swoje usługi w miejscach publicznych prostytutki. Spenalizowano także niedopełnienie podstawowych obowiązków wynikających z władzy rodzicielskiej, jeżeli prowadziło to popełniania przez nieletniego czynu zabronionego ${ }^{112}$.

Skupiński podkreślał fakt zamieszczenia w projekcie z 1970 r. szeregu czynów istotnie odbiegające od tradycyjnej grupy wykroczeń godzących w działalność administracji państwowej. W porównaniu z wykroczeniami o rodowodzie administracyjnym tzw. wykroczenia „kryminalne” cechowała nie tylko większa społeczna szkodliwość, lecz także fakt posiadania bardziej skomplikowanych ustawowych stanów faktycznych. Wśród ich znamion nieporównywalnie większą rolę odgrywały znamiona strony podmiotowej, zwłaszcza kwestia rodzaju winy oraz okoliczności wyłączających winę. Inne znaczenie zyskiwała kwestia form oraz stadiów popełnienia wykroczenia, która została uregulowana w oparciu o recypowane rozwiązania części ogólnej prawa karnego. Wzgląd na szerokie uwzględnianie strony podmiotowej wkroczeń „kryminalnych” skutkował oparciem części ogólnej projektu z 1970 r. na założeniu prewencji indywidualnej. Bliskie powiązania projektu z kodeksem karnym skutkowały zepchnięciem na dalszy plan celów ogólnoprewencyjnych, które odgrywały główną rolę przy wykroczeniach związanych z działalnością administracji ${ }^{113}$.

$\mathrm{Na}$ istotne osłabienie więzów łączących prawo wykroczeń z działalnością administracji państwowej wskazywał uczeń A. Gubińskiego L. Falandysz, zajmujący się w początkowym okresie kariery naukowej problematyką wykroczeń przeciwko porządkowi i spokojowi publicznemu. Falandysz krytycznie ocenił zasadność zamieszczenia rozdziału poświęconego tej grupie wykroczeń na samym początku części szczególnej projektu. Eksponowanie czynów godzących porządek i spokój publiczny uznał za działanie podyktowane wyłącznie względami tradycji ustawodawczej, lecz nie znajdujące uzasadnienia merytorycznego w świetle zawartości części szczególnej projektu. Najwięcej

112 J. Skupiński, Model orzecznictwa w sprawach o wykroczenia, „PiP” 1970, nr 8-9, s. 274.

113 Ibidem. s. 274-275. 
uwagi projekt poświęcał wykroczeniom przeciwko bezpieczeństwu w komunikacji, zaś kolejne miejsca zajmowały wykroczenia godzące w bezpieczeństwo osób lub mienia oraz interesy konsumentów. Zdaniem Falandysza nowe oblicze części szczególnej projektu stanowiło konsekwencję zmiany charakteru prawa o wykroczeniach, które przestało być zbiorem tradycyjnych, subsydiarnych przepisów o wykroczeniach porządkowych. Wskutek uwzględniania przez twórców projektu aktualnych założeń polityki karnej oraz potrzeb życia społecznego prawo wykroczeń stało się samodzielną gałęzią prawa karnego chroniącą szeroki zakres dóbr społecznych ${ }^{114}$.

Falandysz krytycznie oceniał zbyt duże znaczenie praktyczne przepisu art. 50 projektu, który w sposób syntetyczny obejmował liczne stany faktyczne związane $\mathrm{z}$ naruszeniami spokoju i porządku publicznego ${ }^{115}$. Omawiany artykuł powstał w wyniku połączenia trzech szeroko stosowanych w praktyce klasycznych przepisów porządkowych, z których dwa przewidywało obowiązujące p.ow ${ }^{116}$. Trzecim był najczęściej stosowany w praktyce kolegiów stosowny przepis karny ustawy o zwalczaniu alkoholizmu ${ }^{117}$. Według ustaleń Falandysza w oparciu o zgrupowane w art. 50 projektu z 1970 r. przepisy kolegia wymierzały dotychczas około $35 \%$ ogółu orzeczeń o ukaraniu. W tej liczbie prawie $90 \%$ skazań dotyczyło naruszenia spokoju i porządku publicznego przez sprawców znajdujących się pod wpływem alkoholu, czyli tzw. wykroczeń ,alkoholowych”. Nie bez racji Falandysz określał art. 50 projektu jako sformułowany w trzech zdaniach, specyficzny „mały kodeks karny”. Znamiona określonego w nim wykroczenia obok godzenia w spokój i porządek publiczny, obejmowały także zakłócenie spoczynku nocnego albo wywołanie zgorszenia w miejscu publicznych. Tak sformułowany przepis nie wytyczał w sposób dostatecznie jasny granic odpowiedzialności karnej, co stwarzało niebezpieczeństwo jego stosowania w różnych sytuacjach faktycz-

114 L. Falandysz, Wykroczenia przeciwko porządkowi i spokojowi publicznemu, „PiP” 1970, nr 11, s. 708-709.

115 Art. 50 projektu prawa o wykroczeniach z 1970 r. stanowił: „kto krzykiem, hałasem, alarmem lub innym wybrykiem zakłóca spokój, porządek publiczny, spoczynek nocny albo wywołuje zgorszenie w miejscu publicznym, podlega karze aresztu do 2 miesięcy, grzywny do 3000 złotych albo karze nagany. Kwalifikowana postać tego wykroczenia miała miejsce z uwagi na chuligański charakter czynu lub popełnienie go pod wpływem alkoholu. Postać kwalifikowana zagrożona była karami aresztu, ograniczenia wolności lub grzywny w maksymalnym wymiarze.

116 Były to art. 28 p.ow. penalizujący zakłócanie spokoju publicznego krzykiem, hałasem, alarmem lub innym wybrykiem oraz art. 30 p.o.w. przewidującego zakłócanie spoczynku nocnego poprzez uporczywe wybryki. D. Egierska, Artykut 50 projektu prawa o wykroczeniach, „ZKA” 1970, nr 3, s. 15.

117 Art. 27 ustawy z dnia 10 grudnia 1959 r. o zwalczaniu alkoholizmu (Dz. U. nr 69, poz. 434) przewidywał karę aresztu do 3 miesięcy lub grzywny do 4500 złotych (czyli w maksymalnym wymiarze tych kar orzekanych przez kolegia) wobec sprawców, którzy w stanie nietrzeźwości dopuścili się zakłócania porządku publicznego lub wywołali zgorszenie w miejscu publicznym lub w zakładzie pracy. 
nych. Dlatego Falandysz traktował go jako stojący w sprzeczności z zasadą nullum crimen sine lege, a zarazem podważający funkcję gwarancyjną prawa karnego ${ }^{118}$.

Autor ten powoływał się na doświadczenia wyniesione z praktyki stosowania przez kolegia przepisów karnych ustawy „,antyalkoholowej”, które były nadużywane w celu pociągania do odpowiedzialności karno-administracyjnej sprawców przestępstw „,chuligańskich” i prywatnoskargowych. Ponadto przepisy te służyły za podstawę karania przez kolegia prostytutek i innych osób z tzw. „marginesu wielkich miast”. Odpowiedzialność karno-administracyjna tej kategorii osób opierała się na kryterium podmiotowym w postaci wykolejenia społecznego na tle nałogowego lub chronicznego alkoholizmu. Na dalszy plan schodziło kryterium przedmiotowe w postaci popełnienia przez sprawcę czynu zabronionego, gdyż jako wykroczenie przeciwko porządkowi publicznemu kwalifikowano sam fakt pozostawania w stanie upojenia alkoholowego. Celem zapobieżenia tego rodzaju patologiom w przyszłości Falandysz postulował bardziej ostre i precyzyjne określenie znamion wykroczenia regulowanego przez art. 50 projektu oraz odrębne uregulowanie form jego popełnienia. W pierwszej formie czyn przybierałby postać zakłóceniu spokoju publicznego lub spoczynku nocnego. Drugą stanowiłoby dokonanie owego zakłócenia pod wpływem alkoholu lub zachowanie prowadzące do naruszenia porządku publicznego. Falandysz opowiadał się za rezygnacją ze zbędnej jego zdaniem przesłanki ,chuligańskiego charakteru czynu” przy kwalifikowanej postaci wykroczenia, gdyż w praktyce była ona utożsamiana ze stanem upojenia alkoholowego sprawcy ${ }^{119}$.

Również E. Iserzon stał na stanowisku przynależności prawa wykroczeń do obszaru prawa karnego. Autor ten operował argumentem w postaci traktowania przez twórców projektu wykroczeń i przestępstw jako zjawisk rodzajowo jednakowych, różniących się jedynie stopniem społecznego niebezpieczeństwa. Jego zdaniem fakt ten przesądzał o przejściu prawa wykroczeń ,pod skrzydła znakomicie rozbudowanej i dysponującej doskonałymi osiągnięciami i środkami badawczymi nowoczesnej nauki prawa karnego". Wobec uznania za czyn tożsamy rodzajowo z przestępstwem wykroczenie przestało być przedmiotem zainteresowania nauki prawa administracyjnego, aczkolwiek jej dział poświęcony orzecznictwu karno-administracyjnemu miał „W ramach prawa administracyjnego bardzo pomyślne warunki rozwoju"120.

$\mathrm{Na}$ występowanie bliskich powiązań pomiędzy prawem karnym a prawem wykroczeń wskazywano podczas sesji naukowej poświęconej głównym problemom kodyfikacji prawa karno-administracyjnego, którą w październi-

118 L. Falandysz, Wykroczenia przeciwko..., s. 711.

119 Ibidem, s. 712.

120 E. Iserzon, Uwagi do projektów materialnego i formalnego prawa o wykroczeniach, „PiP” 1970, nr 8-9, s. 287. 
ku 1970 r. zorganizował Instytut Nauk Prawnych Polskiej Akademii Nauk. Dyskusję nad projektem prawa o wykroczeniach prowadzili reprezentujący Katedrę Prawa Karnego UW L. Falandysz i L. Kubicki. Ich zdaniem bliski związek prawa wykroczeń z prawem karnym wyrażał się w przyjęciu przez projekt zasad odpowiedzialności w drodze recepcji rozwiązań części ogólnej kodeksu karnego. Specyfika wykroczeń jako drobnych czynów karalnych uzasadniała modyfikację niektórych instytucji prawa karnego w kierunku ich uproszczenia, lecz w opinii niektórych uczestników dyskusji twórcy projektu posunęli się zbyt daleko pomijając niektóre potrzebne przepisy. Kwestionowano m.in. brak regulacji dotyczących problematyki błędu co do faktu, którą w myśl sugestii zawartej w uzasadnieniu projektu z 1970 r. kolegia miały rozstrzygać w oparciu o zasady ustalone przez doktrynę. Uznając odsyłanie do konstrukcji pozaustawowych za dalece niefortunny zabieg legislacyjny, postulowano wprowadzenie przepisu określającego niekaralność błędu do faktu przy wykroczeniach umyślnych. Przedmiotem wątpliwości wyrażanych przez uczestników dyskusji był także sposób ujęcia przez twórców projektu podstaw orzekania kary ograniczenia wolności. Wobec mechanicznego powielenia rozwiązań kodeksu karnego wyrażano obawę, iż wiele elementów reedukacyjnych tej kary może w ogóle nie wystąpić w praktyce ${ }^{121}$.

Omawiając część szczególną projektu z 1970 r. uczestnicy zorganizowanej przez PAN sesji naukowej zwrócili uwagę na zbyt ogólnikowo sformułowaną dyspozycję przepisu przewidującego karalność demonstracyjnego okazywania lekceważenia dla instytucji państwowej lub organizacji społecznej ${ }^{122}$. Twórcom projektu zarzucano mechaniczną recepcję jednego z artykułów obowiązującego p.ow ${ }^{123}$, bez zwrócenia uwagi na negatywne doświadczenia jego praktycznego stosowania w okresie międzywojennym. Kontrowersyjną kwestię karalności publicznych przejawów prostytucji ${ }^{124}$ poruszył krymino$\log$ S. Batawia, zwracając uwagę na fakt częstego uprawiania nierządu przez

${ }^{121}$ L. Falandysz, Sesja naukowa w INP PAN poświęcona projektom kodyfikacji prawa karnoadministracyjnego, „PiP” 1971, nr 2, s. 378.

${ }^{122} \mathrm{~W}$ myśl art. 49 projektu „Kto w miejscu publicznym demonstracyjnie okazuje lekceważenie dla instytucji państwowej lub organizacji społecznej, podlega karze aresztu, ograniczenia wolności albo grzywny".

${ }^{123}$ Art. 48 projektu wzorowany był na art. 18 p.o.w., z którego przejęto karalność demonstracyjnego lekceważenia. Utrzymano nazwę ,instytucje państwowe”, natomiast usunięto termin „Państwo Polskie”. W jego miejsce wprowadzono określenie „organizacja społeczna”. Znacznemu zaostrzeniu - do maksymalnej wysokości przewidzianej w projekcie uległy sankcje karne, podczas gdy p.o.w. przewidywała jedynie 2 tygodnie aresztu lub 750 złotych grzywny. Zestawienie przepisów projektu prawa o wykroczeniach ze wskazaniem ich źródeł $i$ wprowadzonych zmian, IPN BU MSW II 514, część II, s. 97.

124 Projekt przewidywał karalność postępowania, które polega na natarczywym, narzucającym się lub w inny sposób naruszającym porządek publiczny nagabywaniu osoby (niekoniecznie płci odmiennej) celem dokonania z nią czynu nierządnego. D. Egierska, J. Smereczański, Projekt prawa o wykroczeniach, „NP” 1969, nr 4, s. 535-536. 
kobiety uzależnione od alkoholu lub w inny sposób społecznie wykolejone. Opierając się na danych statystycznych starał się wykazać, iż rozmiar zjawiska prostytucji w Polsce nie stanowił uzasadnienia dla jego zwalczania przy pomocy represji karnej. Jego zdaniem przepis projektu przewidujący karalność uprawiania prostytucji $\mathrm{w}$ miejscach publicznym będzie nadużywany w celu szantażowania prostytutek, zwłaszcza tych najbardziej zdegenerowanych. Przychylając się do poglądów Batawii uczestnicy sesji naukowej postulowali skreślenie tego przepisu, tym bardziej że inne artykuły projektu dostatecznie chroniły porządek publiczny ${ }^{125}$.

Nawiązano także do powszechnie wysuwanych podczas dyskusji nad projektem z 1970 r. zastrzeżeń dotyczących karalności „naruszenia podstawowych obowiązków wynikających z władzy rodzicielskiej”. Karalność ta była przewidziana w sytuacji, gdy nieletni dopuścił się czynu zabronionego, który świadczył o jego demoralizacji ${ }^{126}$. Zdaniem przedstawicieli nauki podstawowym mankamentem tego rozwiązania było niezamieszczenie dodatkowych kryteriów wskazujących, które obowiązki rodzicielskie miały charakter podstawowy i w jaki sposób ich naruszenie rzutowało na demoralizację nieletniego. Brak tych kryteriów stwarzał szerokie pole dla dowolnej interpretacji zawartych w przepisie ogólnikowych sformułowań przez organy orzekające. Dostrzegając społeczną potrzebę utrzymania tego przepisu z uwagi na przewidziane w nim ,zagrożenie rodziców postępowaniem przed kolegium”, postulowano jego poprawienie $\mathrm{w}$ drodze przyjęcia określenia „rażące naruszenie obowiązków rodzicielskich"127.

Wysuwane przez przedstawicieli nauki zastrzeżenia wobec niektórych przepisów części szczególnej projektu z 1970 r. w pośredni sposób uderzały w sprawujący zwierzchni nadzór nad orzecznictwem kolegiów resort spraw wewnętrznych. Wydawane w ramach nadzoru wytyczne dla kolegiów sprzyjały bowiem wykorzystywaniu orzecznictwa karno-administracyjne jako instrumentu ograniczania zjawisk patologicznych ${ }^{128}$. Wyrazem tej tendencji było zamieszczenie w projekcie z 1970 r. ogólnikowej definicji chuligańskiego charakteru wykroczenia ${ }^{129}$, która zawierała trudne do sprecyzowania kryteria

125 Naukowcy o wykroczeniach, „PiŻ” 1970, nr 23, s. 5.

126 Przepis art. 102 projektu przewidywał odpowiedzialność karną osoby sprawującej nad nieletnim władzę rodzicielską, jeżeli osoba ta dopuściła do popełnienia przez nieletniego czynu karalnego, świadczącego o jego demoralizacji. Przesłanką pociągnięcia do odpowiedzialności było niedopełnienie podstawowych obowiązków wynikających z faktu sprawowania władzy rodzicielskiej. Pod pojęciem tym twórcy projektu rozumieli obowiązek starannej opieki nad dzieckiem i kierowania nim, np. dopilnowanie, aby dziecko uczęszczało do szkoły, nie przebywało w złym towarzystwie, czy nie piło wódki. D. Egierska, Nowe wykroczenia, „ZKA” 1969, nr 5, s. 14-15.

127 L. Falandysz, Sesja naukowa..., s. 379.

128 Szerzej na ten temat M. Łysko, Orzecznictwo karno-administracyjne $w$ walce $z$ alkoholizmem w okresie gomulkowskim, „Z Dziejów Prawa”, t. 4 (12), Katowice 2011.

129 Według zamieszczonej w § 5 art. 46 projektu z 1970 r. definicji „Charakter chuligański mają wykroczenia polegające na umyślnym godzeniu w porządek i spokój publiczny, albo umyśl- 
o charakterze ocennym. Jak słusznie zauważył L. Falandysz, tak sformułowana definicja sprzyjała praktyce kwalifikowania przez organy ścigania i kolegia jako „chuligańskich” wykroczeń popełnianych przez osoby zaliczane do tzw. marginesu społecznego, czyli prostytutki, włóczęgów i żebraków ${ }^{130}$.

Zajmująca się ostateczną redakcją projektu prawa o wykroczeniach podkomisja sejmowa, w której pracach jako rzeczoznawca uczestniczył A. Gubiński, pozostawiła bez zmian rozwiązania budzące kontrowersje wśród przedstawicieli nauki. Za ich pozostawieniem w przyszłej kodyfikacji materialnego prawa wykroczeń opowiadały się czynniki oficjalne, z wszechwładnym resortem spraw wewnętrznych na czele. Oficjalnym powodem nieuwzględnienia krytycznych uwag wysuwanych przez naukowców miała być powszechna akceptacja podstawowych założeń nowego prawa o wykroczeniach przez społeczeństwo podczas zakrojonej na szeroką skalę dyskusji nad projektem. Spośród wprowadzonych przez podkomisję sejmową zmian i poprawek na uwagę zasługuje propozycja opatrzenia projektu tytułem kodeks wykroczeń. Jej uzasadnienia podjął się przewodniczący Komisji Wymiaru Sprawiedliwości, a zarazem wybitny cywilista J. Wasilkowski. Występując w imieniu klubu poselskiego PZPR, Wasilkowski podkreślał nadrzędne znaczenie prawa materialnego względem przepisów procesowych, które zamieszczono w kodeksie postępowania w sprawach o wykroczenia. Utrzymanie tytułu ,prawo o wykroczeniach" mogłoby spotkać się z nieprzychylnym przyjęciem ze strony opinii publicznej, gdyż w pojęciu przeciętnego obywatela kodeks był czymś więcej aniżeli zwykłą ustawą ${ }^{131}$.

XVI. Zwieńczeniem prac nad kodyfikacją prawa wykroczeń Polski Ludowej było uchwalenie przez Sejm PRL 20 maja 1971 r. ustawy Kodeks wykroczeńn ${ }^{132}$, Kodeks postępowania w sprawach o wykroczenia ${ }^{133}$ oraz Ustawy o ustroju kolegiów do spraw wykroczeń ${ }^{134}$. Tytuły ustaw składających się na kodyfikację prawa wykroczeń miały potwierdzać fakt powstania nowej samodzielnej dziedziny prawa, pozostającej $\mathrm{w}$ bliskim związku z prawem karnym ${ }^{135}$. Odrzucono powszechnie funkcjonujące w ustawodawstwie i dotychczasowej praktyce określenie prawo karno-administracyjne, które pod-

\footnotetext{
nym niszczeniu lub uszkadzaniu mienia, jeżeli sprawca działał publicznie oraz w rozumieniu powszechnym bez powodu lub z oczywiście powodu, okazując przez to lekceważenie podstawowych zasad porządku prawnego".

${ }^{130}$ Wskazywał na to zwłaszcza L. Falandysz, Wykroczenie zakłócenia porządku publicznego. Warszawa 1974, s. 155.

131 Biuletyn nr 335/V kad. Komisji Spraw Wewnętrznych oraz Komisji Wymiaru Sprawiedliwości z dnia 4 marca 1971 r., s. 4-5.

132 Dz. U. nr 12, poz. 114.

133 Dz. U. nr 12, poz. 116.

134 Dz. U. nr 12, poz. 118.

135 J. Bafia, Kodyfikacja prawa o wykroczeniach, „PiP” 1971, nr 10, s. 507.
} 
kreślało służebną rolę prawa wykroczeń wobec administracji państwowej. Leżące u podstaw kodyfikacji z 1971 r. założenie, iż materialne prawo wykroczeń spełnia podobne funkcje co prawo karne ${ }^{136}$, znalazło swój wyraz na gruncie przepisów kodeksu postępowania w sprawach o wykroczenia. W wyniku szerokiego uwzględnienia rozwiązań procedery karnej postępowanie przed kolegium ukształtowano na podobieństwo procesu przed sądem karnym $^{137}$. Na gruncie tej teorii przedstawiciele nauki wysuwali postulaty poddania orzecznictwa kolegiów pełnej kontroli sądowej. Domagano się także odebranie organom administracji spraw wewnętrznych prawa wydawania wytycznych dotyczących kierunków polityki karnej w sprawach o wykroczenia. Krytycznie oceniano funkcjonujące pod kontrolą MSW kolegia do spraw wykroczeń, których orzecznictwo cechowała schematyczna represyjność oraz nastawienie na realizację celów tego resortu, zwłaszcza w okresie kryzysów politycznych $^{138}$.

Wejście w życie nowej kodyfikacji prawa wykroczeń skutkowało dalszym wzrostem zainteresowania przedstawicieli doktryny nową gałęzią szeroko pojmowanego prawa karnego. W latach siedemdziesiątych ukazały się liczne opracowania poświęcone nie tylko problematyce materialnego prawa wykroczeń, lecz także zagadnieniom procesowym. Spośród nich na podkreślenie zasługuje monografia J. Skupińskiego ${ }^{139}$, która stanowiła pierwsze teoretyczne ujęcie polskiego modelu prawa wykroczeń na tle rozwiązań innych państw. Samodzielny charakter prawa wykroczeń sprzyjał wprowadzeniu jego nauczania do programu wyższych studiów prawniczych jako odrębnego od prawa karnego przedmiotu. Zakres tego przedmiotu obejmował również postępowanie w sprawach o wykroczenia, które jeszcze w latach sześćdziesiątych było wykładane na uczelniach jako szczególne postępowanie administracyjne ${ }^{140}$. Dla celów dydaktyki prawa wykroczeń ukazały się podręczniki autorstwa A. Gubińskiego ${ }^{141}$ oraz A. Marka ${ }^{142}$. Zostały one ocenione wysoko z uwagi na dobrą systematykę oraz zwięzłość, przy jednoczesnym zachowaniu pełnej ścisłości naukowej ${ }^{143}$.

Kolejnego ważnego impulsu dla rozwoju nauki prawa wykroczeń dostarczyła przeprowadzona w 1990 r. gruntowna reforma ustrojowa, która uniezależniając kolegia od wpływu organów administracji, włączyła je w system

136 H. Rot, Problemy kodyfikacji prawa PRL, Wrocław 1978, s. 108.

137 Z. Leoński, Istota postępowania w sprawach o wykroczenia, „PiP” 1973, nr 3, s. 91.

138 A. Marek, Problemy reformy polskiego prawa wykroczeń. Refleksje na tle historycznym i porównawczym, w: Księga pamiątkowa ku czci prof. K. Buchały, Kraków 1994, s. 195-196.

139 J. Skupiński, Model polskiego prawa o wykroczeniach, Warszawa 1974.

140 A. Marek, Problemy reformy..., s. 196.

141 Prawo wykroczeń, Warszawa 1973.

142 Prawo wykroczeń, Warszawa-Łódź 1975.

143 M. Siewierski, Wprowadzenie do studiów nad postepowaniem w sprawach o wykroczenia, „Zeszyty Naukowe Akademii Spraw Wewnętrznych” 1976, nr 14, s. 51. 
wymiaru sprawiedliwości ${ }^{144}$. Wprowadzenie sądowej kontroli orzecznictwa kolegiów skutkowało zacieśnieniem więzów łączących prawo wykroczeń z prawem karnym. Dalszemu ich zbliżeniu służyło poddanie w 2001 r. rozpatrywania spraw o wykroczenia wyłącznej właściwości sądów ${ }^{145}$. Likwidacja kolegiów oznaczała koniec dualizmu w zakresie organów orzekających, wskutek czego odpadł jeden z istotnych argumentów przemawiających za odrębnością wykroczeń od przestępstw ${ }^{146}$. Pomimo to dzisiejsza nauka nie kwestionuje teorii przyjmującej wysokość zagrożenia karą oraz kryterium materialne - obecnie występujące pod nazwą społecznej szkodliwości czynu - jako czynników decydujących o odrębności wykroczeń od przestępstw. Podobnie jak w latach sześćdziesiątych przedstawiciele nauki dosyć zgodnie podkreślają, iż różnica pomiędzy wykroczeniem a przestępstwem wyraża się w odmiennym natężeniu społecznej szkodliwości czynu. Wprawdzie wykroczenia stanowią obecnie samodzielną kategorię czynów karalnych, lecz zasady odpowiedzialności za nie oparto na rozwiązaniach części ogólnej kodeksu karnego z 1997 r. ${ }^{147}$ Nikt też nie podaje w wątpliwość stworzonej w okresie prac kodyfikacyjnych teorii o przynależności prawa wykroczeń - jako samodzielnej dziedziny - do obszaru szeroko pojmowanego prawa karnego ${ }^{148}$.

Stworzony przy współudziale przedstawicieli nauki doktryny kodeks wykroczeń okazał się na tyle dobry, iż po upadku systemu komunistycznego trzon jego rozwiązań nie uległ istotnym zmianom. Dzisiejsza nauka prawa jako udaną ocenia technikę samodzielnego kształtowania rozwiązań części ogólnej kodeksu w drodze odpowiedniej recepcji instytucji prawa karnego ${ }^{149}$. Wobec utrzymania karalności publicznych przejawów prostytucji oraz penalizacji niedopełnienia podstawowych obowiązków wynikających $\mathrm{z}$ władzy rodzicielskiej nie straciły na aktualności krytyczne uwagi pod adresem tych przepisów wysuwane przez naukowców na początku lat siedemdziesiątych. Po dzień dzisiejszy w niezmienionej postaci funkcjonuje w kodeksie wykroczeń negatywnie oceniony przez świętej pamięci L. Falandysza przepis zawierający szereg stanów faktycznych związanych z naruszeniami spokoju i porządku publicznego. Fakt obowiązywania tego rodzaju rozwiązań należy ocenić jako niechlubne dziedzictwo systemu komunistycznego, a zarazem ar-

144 Na mocy ustawy z dnia 8 czerwca 1990 r. o zmianie ustaw: Kodeks postepowania karnego, Kodeks postepowania w sprawach o wykroczenia, o ustroju kolegiów do spraw wykroczeń i Kodeks pracy (Dz. U. nr 43, poz. 251).

145 A. Marek, Prawo wykroczeń, Warszawa 2006, s. 18-19.

146 T. Bojarski (red.), Kodeks wykroczeń. Komentarz, Warszawa 2013, s. 35-36.

147 T. Grzegorczyk (red.), Kodeks wykroczeń, Warszawa 2013, s. 25-27.

148 Prawo wykroczeń jest traktowane jako gałąź szeroko rozumianego prawa karnego. Wspólnie z prawem karnym sensu stricto (dotyczącym przestępstw) bywa określane jako powszechne prawo karne. M. Błaszczyk, W. Jankowski, M. Zbrojewska, Prawo i postepowanie $w$ sprawach o wykroczenia, Warszawa 2013, s. 4.

149 T. Bojarski (red.), op. cit. 15. 
gument uzasadniający potrzebę przeprowadzenia kompleksowej reformy materialnego prawa wykroczeń.

\author{
PARTICIPATION OF LAW THEORISTS AND LAW TEACHERS \\ IN THE CODIFICATION WORK \\ ON THE SUBSTANTIVE LAW OF MISDEMEANOURS \\ IN THE POLISH PEOPLE'S REPUBLIC
}

\begin{abstract}
Summary
The codification works on the substantive law of misdemeanours in the Polish People's Republic were carried out in the period 1960-1971 under the supervision of the department of internal affairs, which supported the administrative concept of misdemeanours and regarded them as punishable but distinguishable from crime. This theory was subsequently challenged by law theorists and university teachers specializing in criminal and administrative law. Voices that called for reinstatement of the misdemeanours as criminal acts governed by criminal law were also raised during the public debate on the new law on misdemeanours. The distinction drawn between misdemeanours and offences and their further artificial separation was based on the examples taken from the Soviet Union where the "character and degree of social danger of the crime". These Soviet-based solutions were later criticised, but postulates formulated by the doctrine were only recognised in the second half of the sixties of the twentieth century. The general part of the new code was largely based on the provisions of the general part of the former penal code. Its detailed part, however, referred to a number of factual circumstances of acts of general criminal nature which formerly were regarded as petty crime. The practical reasons connected with the functioning of the penal and administrative decisions in the internal structures of the department of internal affairs constituted the foundations for the treating misdemeanours as an independent sector of a broadly understood criminal law. There was no return either to the pre-war conceptions that determined a misdemeanour as the lowest category of crime, despite the fact many common features were identified as applicable to both categories. The distinction between both punishable acts (crime and misdemeanour) was made based on the potential "degree of social danger" as well as the available penalty for a given act. This approach was then adopted and reflected in the contemporarily binding Code of Misdemeanours of 1971. Its general part turned out to be sound and good enough even after the political transformations of 1981 and has only undergone minor amendments since.
\end{abstract}




\section{LA PARTICIPATION DES REPRÉSENTANTS DU MONDE DES SCIENCES AUX TRAVAUX SUR LA CODIFICATION DU DROIT MATÉRIEL DES CONTRAVENTIONS EN RÉPUBLIQUE POPULAIRE DE POLOGNE}

\section{Résumé}

Les travaux sur la codification du droit substantiel des contraventions en République populaire de Pologne sont menés durant la période 1960-1971. Les travaux de codification sont dirigés par le ministère de l'intérieur qui agit conformément à la conception administrative du droit des contraventions, par conséquent, les contraventions sont considérées comme actes passibles d'une peine et sont complètement distincts du crime. Cette théorie est contestée par les représentants du monde des sciences du droit pénal et droit administratif qui participent aux travaux menés par la commission de codification. Même pendant le débat public sur les projets concernant le droit des contraventions, la doctrine réclame que l'on remette le droit des contraventions sous l'aile du droit pénal. Ainsi est critiquée toute tentative de séparer artificiellement les contraventions des crimes, sur la base du critère qui est le niveau du danger pour la société résultant de l'acte, le critère ayant été emprunté à l'oeuvre de la science soviétique. Les postulats de la doctrine sont pris en compte par les facteurs formels seul dans la seconde moitié des années soixante, ce qui se traduit par la rédaction, dans les projets publiés à l'époque, de la définition de la contravention à l'instar du crime. Les institutions de la partie générale de la future codification s'inspirent des solutions issues de la partie générale du code pénal. Dans cette dernière, on retrouve bien des situations réelles concernant les contraventions, ayant trait au crime général, lesquelles ont constitué avant les petits délits. Les raisons de nature pratique, liées au fonctionnement de la jurisprudence d'ordre pénal et administratif dans les structures du ministère de l'intérieur, deviennent la base permettant de traiter le droit des contraventions comme une section à part du droit pénal, au sens large du terme. On ne revient plus aux concepts d'avant gueurre définissant les contraventions comme catégorie inférieure des crimes, même si l'on souligne bien des caractéristiques communes des deux catégories de ces actes passibles d'une peine. Est considérée comme base permettant de faire la distinction entre les contraventions et les crimes, le critèree du niveau matériel du danger pour la société résultant de l'acte ainsi que le montant du risque pénal. La position de la doctrine trouvera son reflet dans le code des contraventions de 1971 qui reste en application encore à date. La partie générale du code qui tient compte des remarques largement présentées par la doctrine, s'avère si bonne, qu'après le tournant de 1989, elle subit à peine queqlues modifications. 